\title{
Gelir Düzeyi ve Sağlık Hizmet Talebi İlişkisi: Mikro Veriler ile Türkiye Örneği
}

\section{Esra DOĞAN ${ }^{1}$}

\section{$\ddot{O} z$}

Bu çalışmanın amacı Türkiye'deki sağlık hizmet talebi üzerinde, gelir düzeyinin doğrudan ve sağlık hizmeti talebinde geçen sürenin yol açacağı gelir kaybı dolayısıyla da zaman maliyeti nedeniyle gelirin dolaylı etkisini ortaya koyabilmektir. Bu amaç doğrultusunda teorik olarak ilgili literatür ve olgusal olarak da Türkiye'deki sağlık hizmetlerinden yararlananların yararlanma sürecine ilişkin tecrübeleri incelenmiştir. Teorik inceleme sağllk hizmet talebine yönelik modellerin ve bu modellerden hareketle geliştirilen sağlık ekonomisi literatürünün karşılaştırması; olgusal inceleme ise Türkiye İstatistik Kurumu Türkiye Sağlık Araştırması (2016) verilerinin analizi ve değerlendirilmesi ile gerçekleştirilmiştir. Yapılan incelemeler ile de Türkiye'de sağlık hizmeti talebinde gelirin doğrudan etkisi bulunduğu gibi, ortaya çıkan zaman maliyeti dolayısıyla dolaylı etkisi de bulunmaktadır. Sonuç olarak bu çalışmanın bulgularından hareketle, Türkiye'de uygulanan sağlık düzenlemelerinde gelir grupları arasındaki farklılıkların göz önünde bulundurulması gerekliliğinin önemi vurgulanmaya çalışılmıştır.

Anabtar Kelimeler: Gelir Düzeyi, Mikro Veri Analizi, Sağlık Hizmet Talebi, Zaman Maliyeti

\section{Relationship between Income Level and Healthcare Demand: Turkey Sample via Micro} Dataset

\section{Abstract}

The aim of this study is to reveal the direct and indirect effect of income level on health care demand. According to this objective theoretical literature and the facts have been examined in the scope of the experiences of health care beneficiaries. Comparison of healthcare demand models and health economics literature developed from these models has been used for the theorical analysis. Turkey Health Research (2016) data published by Turkey Statistical Institute have been performed for the factual examination. According to this examination it is found that income level has a direct and indirect impact on health care demand in Turkey. As a result, it should be emphasized here that differences between the income groups must be considered in the scope of health regulations in Turkey.

Key Words: Income Level, Micro Data Analysis, Health Care Demand, Time Cost

\section{Atıf İçin / Please Cite As:}

Doğan, E. (2020). Gelir düzeyi ve sağlik hizmet talebi ilişkisi: mikro veriler ile Türkiye örneği. Manas Sosyal Arasttrmalar Dergisi, 9(4), 2376-2392.

Geliş Tarihi / Received Date: 18.03.2020

Kabul Tarihi / Accepted Date: 25.06.2020

\footnotetext{
1 Dr. - Eskişehir Osmangazi Üniversitesi İktisadi ve İdari Bilimler Fakültesi, Türkiye, edogan82@hotmail.com ORCID: 0000-0002-9886-4186
} 


\section{Giriş}

Sağllk hizmet talebi, sağllğa olan talep aracillğıyla türetilmiş bir taleptir. Sağlık hizmet talebi, sağllk talebine bağlı olarak ve arz edilen sağllk hizmetlerinin tüketimi ile ortaya çıkmaktadır. Sağlık ekonomisi kapsamında iktisadın ölçütleri aracıllğıyla tanımlanan sağlık, Dünya Sağlık Örgütü (DSÖ) Anayasasında ise "sadece hastalık ya da kusurun olmaması değil, fiziksel, zihinsel ve toplumsal refahın bütünüyle bulunması hali” olarak tanımlanmaktadır. Sağlık ekonomisi literatüründe Meikirch Sağlık Modeli kapsamında da sağllk, bireylerin potansiyelleri, yaşam talepleri ve toplumsal, çevresel faktörler arasındaki etkileşimden kaynaklanan bir refah halidir (Bircher ve Kuruvilla, 2014).

Sağlığın sahip olduğu geniş kapsamlı tanım, sağlığa ilişkin talebin kapsamını genişlettiği gibi sağlık hizmetlerine olan talebin de kapsamının genişlemesine yol açmaktadır. Buna göre sağılk ekonomisi literatüründe sağlık hizmeti talebini belirleyen faktörlerin fiyatlar, gelir düzeyi, zaman maliyeti, sağlık düzeyi ve hastalı̆̆ın ciddiyeti, sağllk sigortası sahipliği, demografik faktörler ve sunulan sağlık hizmetlerinin kalitesi gibi mikro ve sosyal, kültürel, dini ve politik olmak üzere makro değişkenlerden oluştuğu görülmektedir. Sağllk hizmeti talebine yönelik ilk sistematik modeller ise Michael Grosmann, Jan Paul Acton ve Ronald M. Andersen tarafindan geliştirilmiştir. Andersen (1995) tarafindan sağlık hizmetlerinin toplumsal belirleyicilerine ilişkin genel bir bakış açısı sunmakla birlikte temelde davranışsal nitelikli bir model geliştirilmiştir. Andersan'dan farklı olarak Grosmann ve Acton tarafindan geliştirilen modeller ise mikro değişkenler temelinde kurgulanmıştır. Grosmann Sağllk Talep Modeli hanehalkı üretim teorisi temelinde geliştirilmiş olup, sağlık talebi ile sağllk hizmetlerine yönelik talep arasındaki fark temelinde kurgulanmıştır. Temel bir mal olarak görülen sağlık, sağlık hizmetleri ve zaman değişkenleri aracıllŏ̆yla üretilen tüketim ve yatırım malı niteliğine haizdir. Buna göre modelde tüketim malı niteliği bireylerin tercih fonksiyonunda yer alan ve sağlı̆ın olmadığı zamanların birey için faydasız olarak kabul edilmesi, yatırım malı niteliği ise sağlı̆̆n olmadığı zamanların neden olduğu kayıpların ortadan kalkmasının nakdi değeri olarak kabul edilmektedir. Diğer beşeri sermaye yatırımlarından farkı ortaya koyularak modellenen Grossman sağlk talebi modeli, sağlığın sermaye stoku olarak alındığı ilk talep modelidir. Buna göre belirli sağlık stoğu ile doğan bireyler bu stoğun değerindeki azalmalara karşı sağlık yatırımı yaparak bu değeri tekrar artırabilmektedirler (Grossman, 2017, s. 7-8). Acton tarafindan da Grossmann'in modeli kullanilarak benzer şekilde mikro nitelikli sağlık hizmetlerinde fayda maksimizasyon modeli oluşturulmuştur. Ancak Acton'ın modelinde sağlığa yönelik tüketim ve yatırım malı niteliğinde bir ayrım bulunmayıp, sağlık fiyat, gelir ve zaman değişkenleri ile belirlenen fayda maksimizasyon sorunsalı kapsamında ele alınmaktadır. Buna göre fayda maksimizasyon güdüsüyle hareket eden tüketicinin bütçe kısıtı altında sağlık hizmeti talebinde bulunabilmesi için bedel ödemesi ya da diğer mal ve hizmet talebini azaltması gerekmektedir. Gelirin kazanılmış ve sağllk hizmetlerine ayrllan zaman, dolayısıyla kazanılamamış gelir şeklinde ikiye ayrıldığı modelde, zaman Grossman modeli ile benzer şekilde muhtemel kayıplar olarak içerilmiştir (Acton, 1975).

Grossman ve Acton modelleri, mikro modeller olmalarının yanı sıra sağllk hizmet talebine ayrılan zamanın, çalışma zamanının dolayısıyla da gelir elde etme imkanının alternatifi olarak model kapsamında içerilmesi, gelirin doğrudan etkisinin ötesinde zaman dolayımıyla ortaya çıkan dolaylı etkisinin de ortaya koyulmasına imkan tanımaktadır. Bu çalışma kapsamında ise Grossman ve Acton sağlık hizmet talebi modellerinde yer alan gelirin ve gelir aracıllğıyla zamanın sağlık hizmet talebi üzerindeki etkisi göz önünde bulundurularak, gelirin sadece doğrudan değil, zaman aracılı̆̆ıla ortaya çıkan dolaylı etkisinin de ortaya koyulması amaçlanmaktadır. Bu amaç doğrultusunda öncelikle ilgili literatür incelenmiş sonrasında ise yapılan ampirik çalışmanın bulguları kapsamında değerlendirme ve sonuca yer verilmiştir.

\section{İlgili Literatür}

Sağllk ekonomisi literatüründe sağlık hizmet talebine ilişkin teorik modeller, farklı dönem ve mekan bazında kullanılmış, hatta farklı değişkenlerin eklenmesi aracılığılla genişletilmiştir. Sağlık hizmet talebinin gelir düzeyi ve zaman ile arasındaki ilişkinin literatürde farklı ülke örneklerine ilişkin ampirik nitelikli analizlere dayanan değerlendirmeler kapsamında ele alındığ1 görülmektedir. Söz konusu çalışmalar kapsamında oluşturulan logit modeller ile farklı mekânsal ve zamansal ölçekler dahilinde lojistik regresyon analizleri gerçekleştirilmiştir. İlk olarak gelir düzeyi ele alındığında Malezya (Heller, 1982), Tanzanya (Fredericx, 1998), Madagaskar (Glick, Razafindravonona ve Randretsa, 2000), Güney Afrika (Havemann ve Berg, 2002), Nijerya (Ichoku ve Leibbrandt, 2003), Gürcistan (Gotsadze, Bennett, Ranson ve Gzirishvili, 2005), Vietnam (Xu, Carrin, Phuong, Long, Bayarsaikhan ve Aguilar, 2006; Thuan, Lofgren, Lindholm ve Chuc, 2008), İran (Kermani, Ghaderi ve Yousefi, 2008), Tacikistan (Habibov, 2009), Kamerun (Ntembe, 2009), Çin (Quian, Pong, Yin, Nagarajan ve Meng 2009), Uganda (Darlison ve Okwi, 
2011), Etiyopya (Girma, Jira ve Girma, 2011), Senegal (Lepine ve Nestour 2011) gibi farklı ülkeler için yapılan çalısmaların tamamında gelir düzeyinin sağlık hizmet talebi üzerinde belirleyici olduğu ve gelir düzeyindeki artış ile sağlık hizmet talebinin de yükseldiği sonucuna ulaşılmışır. Bu sonuç, 18 OECD ülkesinin incelendiği bir çalşma (Devaux, 2015) ile de farklı ülkelerdeki benzer sağllk hizmet ihtiyacına yönelik talebin ortaya çıkmasının yüksek gelir gruplarında düşük gelir gruplarına göre daha olası olduğu ampirik olarak ortaya koyularak desteklenmiştir. Bununla birlikte uygulanan sağlık politikalarının doğrudan sağlık hizmet talebi dolaylı olarak da gelir ile ilişkinin incelendiği çalışmalar da bulunmaktadır. Buna göre Endonezya'da uygulanan sağlık programı kapsamında koşullu nakit transferlerinin sağlık hizmet talebine etkisinin incelendiği bir çalışmada (Triyana, 2016), bu transferlerinin sağlık hizmetlerinde fiyatların yükselmesine buna bağlı olarak da düşük gelir gruplarının sağlık hizmet taleplerinin kısıtlanmasına neden olduğu ortaya koyulmuştur. Hanehalkı verileri kullanılarak Pakistan'daki sağlık sisteminin belediyeler düzeyinde incelendiği bir çalışmada (Akbari, Rankaduwa ve Kiani, 2009) ise sadece sağlık hizmetinin zorunluluk olduğu belediyelerde sağllk hizmet talebine yönelik gelir esnekliğinin bulunmadığı sonucuna ulaşılmışır. İtalya için yapılan bir çalışmada (Fabbri ve Monfardini, 2003) da uygulanan sağlık politikaları sonucunda düşük gelir gruplarının pratisyen hekim düzeyinde ortaya çıkan sağlık hizmet taleplerinin uzman hekim düzeyine kaydırılması sağlanırken; kaliteli uzman hekime erişimin sadece yüksek gelir grupları ile sınırlı kaldığı saptanmıştır.

İkinci olarak sağlık kuruluşlarındaki kalabalık ve bekleme süresi ele alındığında zamanın firsat maliyetinin gelir gruplarına göre ve gelirin elde edilme şekline göre değişkenlik gösterdiği görülmektedir. Buna göre Danimarka örneklemi için yapılan bir çalışmada (Arendt, 2012) doğrudan doğruya zamanın firsat maliyetinin gelir gruplarına göre farklılaşıı̆̆ ortaya koyulurken; Almanya hanehalkı verileri ile yapılan çalışmada (Riphahn, Wambach ve Million, 2003) ise kendi işini yapanların sağlık hizmet talebi süresinde ortaya çıkabilecek gelir kaybı nedeniyle sağlık hizmet taleplerinin düşük olduğu sonucuna ulaşılmıştır. Bununla birlikte Filipinler (Hotchkiss, 1998), Suudi Arabistan (Ghanim, 2004), Kibris (Hanson, Yip ve Hsiao, 2004), Eritre (Habtom ve Ruys, 2007), Kenya (Muriithi, 2013) gibi ülkelerde yapılan çalışmaların tamamında kalabalığın ve bekleme süresinin sağllk hizmet talebi üzerinde belirleyici olduğu ve Kenya dışındaki ülkelerin tamamında bekleme süresi arttıkça sağlık hizmet talebinin azaldığı sonucuna ulaşılmıştır. Kenya için yapılan çalışmada ise diğer ülkelerden farklı olarak sağlık kurumlarındaki bekleme süresi arttıkça sağlık hizmet talebinin arttığı saptanmıştır. Bu durum mantıksız gibi görünse de sağlık kuruluşundaki bekleme süresinin artışı ile sağlık personeli ile daha yakın iletişim kurma olanağının oluşması ve özellikle gelir düzeyi düşük olanların sağlık kuruluşunda geçirmekle kaybedecekleri günlük ücret düzeyinin düşük olması neticesinde ortaya çıkan net faydanın yüksek olması halleri, bekleme süresinin görünmez faydaları olarak çalışmada içerilmektedir (Muriithi, 2013).

Sağllk hizmet talebine yönelik Türkiye için yapılan çalışmalar incelendiğinde ise Liu, Çelik ve Şahin (2005), Şenol, Çetinkaya ve Balc1 (2010), Yaylalı, Kaynak ve Karaca (2012), Güneş, Ünlü, Büyükkör ve Birecikli (2016) ile Kutlu ve Ağırbaş (2017) tarafından gerçekleştirilen ampirik analizler ile gelir düzeyindeki artışın sağlık hizmet talebini yükselttiği sonucuna ulaşılmıştır. Türkiye'deki sağlık hizmetlerine yönelik talebin belirleyicilerin saptanması amacıyla Saraçoğlu ve Öztürk (2015) tarafindan yapılan lojistik regresyon temelli çalışmada ise gelir düzeyinin sağlık hizmet talebini doğrudan doğruya etkilediği özellikle de söz konusu talebin özel ya da kamu sağılk -kuruluşları arasındaki dağılımında etkili olduğu ortaya konulmuştur. Bununla birlikte gelir düzeyinin sağlık hizmet talebi üzerindeki etkisinin dolaylı olarak ortaya konulduğu Çukur ve Bekmez (2011) tarafından panel veri analizi ile gerçekleştirilen çalışmada ise gelir düzeyinin sağlık üzerinde doğrudan etkili olduğu kamu sağlık politikaları ve kamu sağlık harcamaları temelli sağllk hizmetlerine erişim de bu etkinin faktörlerinden biri olarak belirtilmiştir (Çukur, 2011, s. 34). Literatürde yer alan ekonometrik analiz temelli çalışmaların yanı sıra Şantaş (2017) tarafindan gerçekleştirilen Dünya Sağlık Örgütü verilerinin ülkelerin gelir düzeyleri temelinde kategorize edilerek değerlendirildiği çalışma ile de yoksullukla mücadelenin beraberinde sağlık ve sağlık hizmet kullanımı üzerinde olumlu etkisinin olacağı sonucuna ulaşılmıştır. Sağlık hizmet talebinde gelirin doğrudan ya da dolaylı etkisinin incelendiği bu çalışmalardan farklı olarak zamanın firsat maliyetinin değerlendirildiği çalışmalar da bulunmaktadır. Buna göre özel hastanelere yönelik talebin Akyürek ve Orhaner (2017) tarafından incelendiği bir çalışmada sağlık hizmetlerinin hızlı ve zamanında sunulması talep üzerinde etkili bir faktör olarak kabul edilirken, zamana verilen önem hastalığın şiddeti arttıkça daha da arttığ1 belirtilmektedir. Bu durum, sağlık hizmetlerine yönelik talebin bütün olarak ele alındığı Gökkaya ve Erdem (2017) tarafından Isparta örneklemine ilişkin yapılan çalışma ile ampirik olarak da desteklenmiştir. 
DOĞAN

Gelir Düzeyi ve Sağlık Hizmet Talebi İlişkisi: Mikro Veriler ile Türkiye Örneği

Bütün bu incelemeler sonucunda gelirin sağlık hizmet talebi üzerindeki etkisi genel bir kabul olarak ortaya çıkmış olmakla birlikte; sağılk hizmet talebi dolayısıyla ortaya çıkacak zaman maliyetinin gelir ile ilișkisi sınırlı olarak ele alınmıştur. Bu doğrultuda sağlık hizmet talebi üzerinde gerek gelirin doğrudan etkisinin gerekse zaman maliyeti dolayısıyla oluşabilecek dolaylı etkinin ortaya koyulması aracilığyla literatürde yer alan gelir ile sağlık hizmet talebi ilişkisinin kapsamının genişletilmesiyle literatüre katkı yapılması hedeflenmektedir.

\section{Ampirik Değerlendirme}

Sağlık hizmet talebi üzerinde gelirin doğrudan etkisine yönelik genel kabul ve bu genel kabul üzerinde dolaylı etkiye sahip olan zaman maliyeti nedeniyle ortaya çıkabilecek gelir kaybının neden olacağı dolaylı etkinin sorgulanması amacıyla amacı ile Türkiye'deki olgusal durumun ortaya konmasına imkan verecek şekilde ampirik bir değerlendirme yapılmıştır.

\section{Araştırmanın Amacı ve Kapsamı}

$\mathrm{Bu}$ araştırmanın amacı sağılk hizmetinin karma mal olma niteliğini sorgulayarak pratikte hangi mal grubu kategorisine dahil olduğunu ortaya koyabilmektedir. Bu doğrultuda araştırma kapsamını, Türkiye'de yerleşik ve farklı gelir düzeylerine sahip hane halkı oluşturmakta olup analize dahil olan örneklem kapsamında 17.242 kişi bulunmaktadır.

\section{Yöntem}

Araştırmanın amacına uygun bir değerlendirme yapabilmek için Türkiye İstatistik Kurumu Başkanlı̆̆ Türkiye Sağlık Araştırması (2016) mikro veri setinden yararlanılmıştır. TÜIK mikro veri setine ilişkin anket formu toplam 444 adet sorudan ve dört bölümden oluşmaktadır. İlk bölüm genel nitelikli demografik ve sosyo-ekonomik özelliklerine, ikinci bölüm 0-6 yaş grubu, üçüncü bölüm 7-14 yaş grubu, dördüncü bölüm ise 15 yaş ve üzeri grubunun sağlık durumlarına ilişkin sorulardan oluşmaktadır. Araştırmanın kapsamı doğrultusunda anket formundaki ilk ve dördüncü bölümde yer alan toplam 194 soru esas alınmıştır. Söz konusu sorulardan ise çalışmanın amacı ile doğrudan doğruya uyumlu olan 30 soruya ilişkin veriler SPSS 16 programında işlenerek analiz edilmiştir.

Analiz sürecinde öncelikle ankete katılanların sağlık durumları ve gelir düzeyleri dağılımını görebilmek için Frekans Analizi yapılmıştır. Daha sonra geliştirilen hipotezler çerçevesinde ilgili değişkenler arasındaki ilişkilerin ortaya konulabilmesi amacıyla çapraz tablolar oluşturulmuştur. Çapraz tablolarda ortaya çıan ilişkilerin anlamlı olup olmadığının değerlendirilebilmesi için öncelikle uygulanacak testlerin belirlenmesi amacıyla serilerin dağılımı incelenmiştir. Bu doğrultuda örneklem büyüklüğü nedeniyle KolmogorovSmirnov testi (McKillup, 2012) uygulanmış ve test sonucunda hesaplanan p değerlerinin $\alpha=0,05$ 'den büyük çıkması nedeniyle serilerin normal dağılıma sahip olduğu tespit edilmiştir (Mertler ve Vannatta, 2005). Normallik varsayımının sağlanmasına bağlı olarak uygulanacak testlerin parametrik testler olduğu sonucuna ulaşılmıştır (Howitt ve Cramer, 2011). Bu doğrultuda iki kategoriye sahip bağımsız değişkenler Bağımsız Örneklem t-testi, en az üç alt kategoriye sahip bağımsız değişkenler ise Tek Yönlü Varyans Analizi (ANOVA) ile test edilmiştir.

Analiz iki temel bölümden oluşmaktadır. İlk bölümde sağlık hizmet talebinde gelirin doğrudan etkisi, ikinci bölümde ise zaman maliyeti nedeniyle gelirin dolaylı etkisinin ortaya çıkıp çıkmadığı incelenmiştir. $\mathrm{Bu}$ doğrultuda iki temel hipotez ve bu temel hipotezi değerlendirmeye imkân veren alt hipotezler oluşturulmuştur. Bu kapsamda çalışmada test edilen hipotezler şu şekildedir:

Tablo 1. Analiz. Hipotezleri

\begin{tabular}{|c|c|c|}
\hline & HİPOTEZ & HİPOTEZ \\
\hline \multirow{2}{*}{$\begin{array}{l}\text { Temel } \\
\text { Hipotez }\end{array}$} & H1: Sağlık hizmet talebinde gelir etkisi ortaya çıkmaktadır. & H2: Sağlık hizmet alımında zaman etkisi ortaya çıkmaktadır. \\
\hline & $\begin{array}{l}\text { H1.1: Genel sağlık durumu gelir düzeyine bağlı olarak } \\
\text { değişkenlik göstermektedir. } \\
\text { H1.2: Sağlık hizmet talebi gelir düzeyine bağlı olarak } \\
\text { değişkenlik göstermektedir. }\end{array}$ & $\begin{array}{l}\text { H2.1:Sağlik hizmeti almada gecikme yaşayanlar genel sağlık } \\
\text { durumuna göre değişkenlik göstermektedir. }\end{array}$ \\
\hline $\begin{array}{l}\text { Alt } \\
\text { Hipotezler }\end{array}$ & $\begin{array}{l}\text { H1.3: Sağlık talebinde bulunanların sağlık kurumu tercih } \\
\text { sebepleri gelir düzeyine bağlı olarak değişkenlik } \\
\text { göstermektedir. } \\
\text { H1.4: Ödeme güçlüğü nedeniyle sağlık talebinde bulunmama } \\
\text { gelir düzeyine bağlı olarak değişkenlik göstermektedir. }\end{array}$ & $\begin{array}{l}\text { H2.2: Sağlık hizmeti almada gecikme yaşayanlar yaşam } \\
\text { faaliyetlerinin k1sıtlanma durumuna göre değişkenlik } \\
\text { göstermektedir. }\end{array}$ \\
\hline
\end{tabular}




\section{Araştırmanın Bulguları}

Araştırmanın bulguları, çalışma kapsamında test edilen hipotezlerin değerlendirilmesine yönelik üç kısımda ele alınmaktadır. Hipotezlerin test aşamasından önce, verilerin güvenilirliğinin sınanması amacıyla Croanbach Alpha Standardized Items güvenilirlik testi yapılmıştır. Standardize edilmiş Alpha değeri 0,63 olarak bulunmuş olup bu değerin 0,60-0,80 (Alpar, 2018) aralığında olması nedeniyle verilerin güvenilir olduğu kabul edilmiştir.

\section{Gelir Düzeyi Bağlamında Sağlık Hizmet Talebine İlişkin Bulgular}

Sağlık hizmet alımında gelirin etkisinin ortaya çıkması, sağlık hizmetinin faydasından yararlananlar bulunurken bu faydadan yararlanmayanların ya da yararlanamayanların da bulunmas halinde gerçekleşecektir. Bu durumun tespitine yönelik genel sağllk durumu ve sağllk hizmet talebinin gelir düzeyine bağlı değişim gösterip göstermediği incelenecektir

\section{Gelir Düzeyi ve Genel Sağlık Durumu İlişkisi}

Gelir düzeyi ile sağlık hizmet talep düzeyi arasındaki ilişkinin incelenmesi ve buradan hareketle bir değerlendirme yapılabilmesi için örneklemin farklı gelir düzeyleri ve farklı sağlık durumundaki hane halkı verisini içermesi gereklidir. Verilerin karşılaştırma ve değerlendirmeye uygunluğunun tespiti amaciyla frekans analizi yapılmıştır.

Tablo 2. Gelir Düreyi Değişkeni için Frekans Analizi Sonuçlar

\begin{tabular}{|c|c|c|}
\hline Gelir Düzeyi & Siklik & Yüzde \\
\hline $0-1264$ & 4290 & 21,4 \\
\hline $1265-1814$ & 5529 & 27,6 \\
\hline $1815-2540$ & 3678 & 18,4 \\
\hline $2541-3721$ & 3354 & 16,8 \\
\hline 3722 ve üzeri & 3163 & 15,8 \\
\hline
\end{tabular}

Örneklem kapsamında beş gelir grubu yer almakta olup, sıklı̆ı̆n düşük gelir gruplarında daha fazla olduğu görülmektedir. Ancak gelir grupları arasındaki yüzde dağılımın yüksek oranlı farkllık göstermemesi nedeniyle, gelir düzeyi temelli karşılaştırma yapabilmek için örneklemin uygun olduğu söylenebilir.

Tablo 3. Genel Sağhk Durumu Değģskeni için Frekans Analizi Sonuclar

\begin{tabular}{|c|c|c|}
\hline Genel Sağlık Durumu & Siklik & Yüzde \\
\hline Çok İyi & 1605 & 8,4 \\
\hline İyi & 10600 & 55,3 \\
\hline Orta & 4901 & 25,6 \\
\hline Kötü & 1852 & 9,7 \\
\hline Çok kötü & 215 & 1,1 \\
\hline
\end{tabular}

Genel sağlık durumu beşli ölçek ile ölçülmeye çalışlımış ve sağlık durumuna ilişkin uç durumlarda oranlar düşerken, dağılımın esas olarak iyi ve orta seviyelerinde sıklık oluşturduğu görülmektedir. Buna göre örneklem kapsamındaki hane halkının ağırlıklı olarak sağlıklı bireylerden oluştuğu söylenebilir. Sağlık durumu düzeyleri arasındaki dağılımın gösterdiği farklılı̆ın yüksek olması nedeniyle, genel sağlık durumu temelli bir karşılaştırma için örneklemin uygun olmadığı söylenebilir.

Genel sağlık durumunun gelir düzeyine bağlı olarak gösterdiği değişikliğin, gelir grupları arasında anlamlı bir farklılık oluşturup oluşturmadığının tespitine yönelik her iki değissken grubu için tek yönlü varyans (ANOVA) analizi yapılmıştır.

Tablo 4. Gelir Düzeyi ve Genel Sağhlk Durumu Ilişkisi için Tek Yönlü Varyans (ANOVA) Analizi Sonuclar

\begin{tabular}{lccccc}
\hline & En Küçük Kareler Toplamı & Serbestlik Derecesi & Ortalama & F Değeri & Anlamlllık \\
\hline Gruplar Aras1 & 601,912 & 4 & 150,478 & 220,542 & 0,000 \\
Grup İçi & 11760,963 & 17,237 & 0,682 & & \\
Toplam & 12362,876 & 17,241 & & & \\
\hline
\end{tabular}

Tek yönlü varyans (ANOVA) analizi sonuçlarına göre gelir düzeyleri arasında genel sağllk durumunun gösterdiği farklllığın anlamlı olduğu (p:0,000) tespit edilmiştir. Bu doğrultuda gelir düzeyine bağlı olarak genel sağllk durumu seviyesinin değişkenlik gösterdiği söylenebilir.

Bu çerçevede gelir düzeyinin temel değişken olması halinde genel sağlık durumunun gösterdiği değişim çapraz tablo ile incelenmiştir. 
DOĞAN

Gelir Düzeyi ve Să̆llk Hizmet Talebi Illişkisi: Mikro Veriler ile Türkiye Örneğgi

Tablo 5. Gelir Düzeyi ile Genel Sağhk Durumu Karşılaștırması

\begin{tabular}{|c|c|c|c|c|c|c|c|c|}
\hline & \multirow{2}{*}{$\begin{array}{l}\text { GELÍR } \\
\text { GRUPLARI }\end{array}$} & \multirow[t]{2}{*}{$D E G \dot{I} S K K E N$} & \multicolumn{6}{|c|}{ GENEL SAGLIK DURUMU } \\
\hline & & & ÇOK IYY & $\dot{I Y Y \dot{I}}$ & ORTA & KÖTÜ & $\begin{array}{c}C O K \\
K \ddot{O} T \ddot{U}\end{array}$ & TOPLAM \\
\hline \multirow{15}{*}{$\begin{array}{l}\text { HANE- } \\
\text { GELİR }\end{array}$} & \multirow{3}{*}{$0-1.264$} & Adet & 206 & 1462 & 1136 & 760 & 107 & 3671 \\
\hline & & Hane-Gelir & $5,6 \%$ & $39,8 \%$ & $30,9 \%$ & $20,7 \%$ & $2,9 \%$ & $100,0 \%$ \\
\hline & & $\begin{array}{l}\text { Genel Sağlık } \\
\text { Durumu }\end{array}$ & $13,3 \%$ & $16,8 \%$ & $23,2 \%$ & $41,0 \%$ & $49,8 \%$ & $21,3 \%$ \\
\hline & \multirow{3}{*}{$1.265-1.814$} & Adet & 377 & 2291 & 1474 & 514 & 51 & 4707 \\
\hline & & Hane-Gelir & $8,0 \%$ & $48,7 \%$ & $31,3 \%$ & $10,9 \%$ & $1,1 \%$ & $100,0 \%$ \\
\hline & & $\begin{array}{l}\text { Genel Sağlik } \\
\text { Durumu }\end{array}$ & $24,3 \%$ & $26,3 \%$ & $30,1 \%$ & $27,8 \%$ & $23,7 \%$ & $27,3 \%$ \\
\hline & \multirow{3}{*}{$1.815-2.540$} & Adet & 287 & 1669 & 904 & 263 & 29 & 3152 \\
\hline & & Hane-Gelir & $9,1 \%$ & $53,0 \%$ & $28,7 \%$ & $8,3 \%$ & $9 \%$ & $100,0 \%$ \\
\hline & & $\begin{array}{l}\text { Genel Sağlik } \\
\text { Durumu }\end{array}$ & $18,5 \%$ & $19,1 \%$ & $18,4 \%$ & $14,2 \%$ & $13,5 \%$ & $18,3 \%$ \\
\hline & \multirow{3}{*}{$2.541-3.721$} & Adet & 349 & 1621 & 756 & 203 & 15 & 2944 \\
\hline & & Hane-Gelir & $11,9 \%$ & $55,1 \%$ & $25,7 \%$ & $6,9 \%$ & ,5\% & $100,0 \%$ \\
\hline & & $\begin{array}{l}\text { Genel Sağlık } \\
\text { Durumu }\end{array}$ & $22,5 \%$ & $18,6 \%$ & $15,4 \%$ & $11,0 \%$ & $7,0 \%$ & $17,1 \%$ \\
\hline & \multirow{3}{*}{3.722 ve üzeri } & Adet & 335 & 1677 & 631 & 112 & 13 & 2768 \\
\hline & & Hane-Gelir & $12,1 \%$ & $60,6 \%$ & $22,8 \%$ & $4,0 \%$ & ,5\% & $100,0 \%$ \\
\hline & & $\begin{array}{l}\text { Genel Sağlık } \\
\text { Durumu }\end{array}$ & $21,6 \%$ & $19,2 \%$ & $12,9 \%$ & $6,0 \%$ & $6,0 \%$ & $16,1 \%$ \\
\hline \multirow{3}{*}{ Toplam } & & Adet & 1554 & 8720 & 4901 & 1852 & 215 & 17242 \\
\hline & & Hane-Gelir & $9,0 \%$ & $50,6 \%$ & $28,4 \%$ & $10,7 \%$ & $1,2 \%$ & $100,0 \%$ \\
\hline & & $\begin{array}{l}\text { Genel Sağlık } \\
\text { Durumu }\end{array}$ & $100,0 \%$ & $100,0 \%$ & $100,0 \%$ & $100,0 \%$ & $100,0 \%$ & $100,0 \%$ \\
\hline
\end{tabular}

Bütün gelir düzeylerinde genel sağlık durumunun ağırlıklı olarak "iyi”" ve "orta" seviyede olduğu görülmektedir. Ancak söz konusu ağırlıklar, gelir düzeyi ile birlikte artış göstermektedir. Buna göre en düşük gelir grubunun \%69,7'lik kısmı "iyi” ve "orta" sağlık seviyede sağllk durumuna sahipken, bu oran en yüksek gelir grubunda \% 82,8'e yükselmektedir. Ayrıca gelir düzeyindeki yükselişle birlikte "kötü" ve "çok kötü” seviyesindeki sağlık durumlarının her bir gelir düzeyi içindeki payı azalırken "çok iyi”" seviyesindeki sağlık durumunun payı da yükselmektedir. Nitekim genel sağlık durumu için uç değer olarak kabul edilen "kötü" ve "çok" kötü" hallerinin de büyük oranda en düşük gelir grubunda bulunduğu (\% 90,8) görülmektedir.

$\mathrm{Bu}$ çerçevede elde edilen bulgular doğrultusunda "H1.1: Genel sağlık durumu gelir düzeyine bağlı olarak değişkenlik göstermektedir” hipotezi kabul edilmektedir.

\section{Gelir Düzeyi ve Sağlık Hizmet Talep Düzeyi}

Sağlık hizmet talebi, yataklı hizmet ve günübirlik hizmet talebi şeklinde iki kategoride ele alınmıştır. Gelir düzeyine bağlı sağlık hizmet talep düzeyinin gösterdiği farklılığın anlamlı olup olmadığına yönelik bağımsız örneklem T testi yapılmıstır.

Tablo 6. Gelir Düzeyi ve Sağhle Hižmet Talebi için Bağzmsız Örneklem T Testi Sonuclar

\begin{tabular}{lccc}
\hline \multicolumn{1}{c}{ Değişken } & T Değeri & Serbestlik Derecesi & Anlam Düzeyi (2 Kuyruklu) \\
\hline Yataklı Hizmet Talebi & $-9,435$ & 2,755 & 0,000 \\
\hline Günübirlik Hizmet Talebi & 2,622 & 1,617 & 0,009 \\
\hline
\end{tabular}

Bağımsız örneklem T testi sonuçlarnna göre gelir düzeyleri arasında sağlık hizmet talebinin gösterdiği farklılı̆ın anlamlı olduğu (p:0,000) tespit edilmiştir. Bu doğrultuda gelir düzeyine bağlı olarak sağllk hizmet talebinde bulunma ve bulunmama halinin değişkenlik gösterdiği söylenebilir.

Her bir hizmet talebinin gelir düzeyine bağlı olarak karşılaştırmalı olarak değerlendirilebilmesi amacıyla, gelir düzeyleri temelindeki dağılımın incelenmesine imkan veren çapraz tablo oluşturulmuştur. 
Tablo 7. Gelir Düreyi ile Sağlık Hižmeti Talep Düreyi Karşılaştorması

\begin{tabular}{|c|c|c|c|c|c|}
\hline & & & $\begin{array}{c}\text { SON 12AY } \\
\text { YATAKLI } \\
\text { HIZMET }\end{array}$ & $\begin{array}{c}\text { SON 12AY } \\
\text { GÜNÜ BIRLIK } \\
\text { HIZZMET }\end{array}$ & $\begin{array}{c}\text { SON } 12 A Y \\
\text { TOPLAM } \\
H \dot{I} Z M E T \\
\text { TALEBI }\end{array}$ \\
\hline \multirow{15}{*}{ HANE-GELİR } & \multirow{3}{*}{$0-1.264$} & Adet & 597 & 2.040 & 2.637 \\
\hline & & Hane-Gelir & $16,3 \%$ & $55,6 \%$ & $71,9 \%$ \\
\hline & & Hizmet & $28,2 \%$ & $20,8 \%$ & $21,3 \%$ \\
\hline & \multirow{3}{*}{$1.265-1.814$} & Adet & 618 & 2.714 & 3.332 \\
\hline & & Hane-Gelir & $13,1 \%$ & $57,7 \%$ & $70,8 \%$ \\
\hline & & Hizmet & $29,2 \%$ & $27,7 \%$ & $27,3 \%$ \\
\hline & \multirow{3}{*}{$1.815-2.540$} & Adet & 341 & 1.734 & 2.75 \\
\hline & & Hane-Gelir & $10,8 \%$ & $55 \%$ & $65,8 \%$ \\
\hline & & Hizmet & $16,1 \%$ & $17,7 \%$ & $18,3 \%$ \\
\hline & \multirow{3}{*}{$2.541-3.721$} & Adet & 294 & 1.640 & 1.934 \\
\hline & & Hane-Gelir & $10 \%$ & $55,7 \%$ & $65,7 \%$ \\
\hline & & Hizmet & $13,9 \%$ & $16,7 \%$ & $17,1 \%$ \\
\hline & \multirow{3}{*}{3.722 ve üzeri } & Adet & 264 & 1.679 & 1.943 \\
\hline & & Hane-Gelir & $9,5 \%$ & $60,7 \%$ & $70,2 \%$ \\
\hline & & Hizmet & $12,5 \%$ & $17,1 \%$ & $16,1 \%$ \\
\hline \multirow{3}{*}{ Toplam } & & Adet & 2.114 & 9.807 & 11.921 \\
\hline & & Hane-Gelir & $12,3 \%$ & $56,9 \%$ & $69,2 \%$ \\
\hline & & Hizmet & $100 \%$ & $100 \%$ & $100 \%$ \\
\hline
\end{tabular}

Anketin yapıldığı dönem itibariyle son 12 ay içinde hane halkı tarafindan sağlık kurumlarından hizmet talep düzeyi toplam \% 69,2 oranında gerçekleşmiştir. Hizmet talebinin önemli kısmı günübirlik taleptir (Toplam talebin \% 82'lik kısmı). Hizmet talep düzeyi, gelir düzeyi bağlamında ele alındığında gelir düzeyindeki yükselişle birlikte yataklı hizmet talebinin azaldığı, günübirlik hizmet talebinin önemli bir farklılık göstermezken sadece en yüksek gelir grup düzeyinde göreli olarak daha yüksek olduğu görülmektedir.

Bu çerçevede elde edilen bulgular doğrultusunda "H1.2: Sağl1k hizmet talebi gelir düzeyine bağlı olarak değişkenlik göstermektedir” hipotezi kabul edilmektedir.

\section{Gelir Düzeyi ve Sağlık Hizmet Talebinde Bulunma Hali İlişkisi}

Örneklem kapsamında sağlık hizmet talebinde bulunan \% 69,2’lik bölümün taleplerini karşılayacak sağlık kurumu tercihi farklı etkenler tarafindan belirlenmektedir. TÜİK tarafindan yapılan ankette söz konusu etkenler sosyal güvence, ucuzluk, yakınlık, başka seçeneğin olmaması, iyi davranma, güvenilirlik, bekletilmeme, daha iyi sağlık hizmeti, tanıdık personel varlığı, sevk edilme, tavsiye, rahatsızlı̆̆ı ciddi olmaması, ilaç temini şeklinde on üç olası sebep olarak yer almıştır. Ancak söz konusu etkenlerin önemli bir kısmının sağlık kurum tercihi üzerindeki etkisinin oldukça düşük olduğu, "sosyal güvence, ucuzluk, yakınlık, başka seçeneğin olmaması, daha iyi sağlık hizmeti ve güvenilirlik" faktörlerinin sağlık kurum tercihi üzerindeki temel belirleyici faktörler olduğu saptanmışır.

Tablo 8. Gelir Düreyi ve Sağhk Kurumu Tercibi İlişkisi için Tek Yönlü Varyans (ANOVA) Analizi Sonuclar

\begin{tabular}{lccccc}
\hline & En Küçük Kareler Toplami & Serbestlik Derecesi & Ortalama & F Değeri & Anlamlılık \\
\hline Gruplar Aras1 & 2626,630 & 4 & 656,658 & 26,638 & 0,000 \\
\cline { 1 - 5 } Grup İçi & 424905,117 & 172,37 & 24,651 & & \\
\cline { 1 - 4 } Toplam & 427531,747 & 172,41 & & & \\
\hline
\end{tabular}

Tek yönlü varyans (ANOVA) analizi sonuçlarına göre gelir düzeyleri arasında sağlık kurumu tercih nedeninin gösterdiği farklılığın anlamlı olduğu (p: 0,0000) tespit edilmiştir. Bu doğrultuda gelir düzeyine bağlı olarak genel sağlık kurumu tercihinde belirleyici olan faktörlerin değişkenlik gösterdiği söylenebilir. Bu nedenle gelir düzeyinde temelinde, sağlık kurumu tercihi üzerinde temel belirleyici niteliğe sahip altı faktöre ilişkin çapraz tablo oluşturulmuştur. 
DOĞAN

Gelir Düzeyi ve Să̆lık Hizmet Talebi İlişkisi: Mikro Veriler ile Türkiye Örneği

Tablo 9. Gelir Düzeyi ile Sağlık Kurum Tercih Nedeni Karşılaştırması

\begin{tabular}{|c|c|c|c|c|c|c|c|c|}
\hline & & & $\begin{array}{c}\text { Sosyal } \\
\text { Güvence }\end{array}$ & Yakın & $\begin{array}{c}\text { Başka } \\
\text { Seçenek } \\
\text { Yok }\end{array}$ & $\begin{array}{c}\text { Daha İyi } \\
\text { Sağlık } \\
\text { Hizmeti }\end{array}$ & Ucuz & Güvenilit \\
\hline \multirow{15}{*}{$\begin{array}{l}\text { HANE- } \\
\text { GELIR }\end{array}$} & \multirow{3}{*}{$0-1.264$} & Adet & 1.579 & 805 & 357 & 301 & 233 & 150 \\
\hline & & Hane-Gelir & $43 \%$ & $21,9 \%$ & $9,7 \%$ & $8,2 \%$ & $6,3 \%$ & $4,1 \%$ \\
\hline & & Sağlık Kurum Tercihi & 21,4 & $19,9 \%$ & $38,6 \%$ & $16 \%$ & $44,4 \%$ & $15,9 \%$ \\
\hline & \multirow{3}{*}{$\begin{array}{l}1.265- \\
1.814\end{array}$} & Adet & 2.242 & 1.047 & 222 & 501 & 152 & 191 \\
\hline & & Hane-Gelir & $47,6 \%$ & $22,2 \%$ & $4,7 \%$ & $10,6 \%$ & $3,2 \%$ & $4,1 \%$ \\
\hline & & Sağlik Kurum Tercihi & $30,4 \%$ & $25,9 \%$ & $24 \%$ & $26,6 \%$ & $29 \%$ & $20,2 \%$ \\
\hline & \multirow{3}{*}{$\begin{array}{l}1.815- \\
2.540\end{array}$} & Adet & 1.438 & 732 & 124 & 355 & 75 & 159 \\
\hline & & Hane-Gelir & $45,6 \%$ & $23,2 \%$ & $3,9 \%$ & $11,3 \%$ & $2,4 \%$ & $5 \%$ \\
\hline & & Sağlık Kurum Tercihi & $19,5 \%$ & $18,1 \%$ & $13,4 \%$ & $18,9 \%$ & $14,3 \%$ & $16,8 \%$ \\
\hline & \multirow{3}{*}{$\begin{array}{l}2.541- \\
3.721\end{array}$} & Adet & 1.174 & 760 & 115 & 374 & 34 & 189 \\
\hline & & Hane-Gelir & $39,9 \%$ & $25,8 \%$ & $3,9 \%$ & $12,7 \%$ & $1,2 \%$ & $6,4 \%$ \\
\hline & & Sağlık Kurum Tercihi & 15,9 & $18,8 \%$ & $12,4 \%$ & $19,9 \%$ & $6,5 \%$ & $20 \%$ \\
\hline & \multirow{3}{*}{$\begin{array}{l}3.722 \text { ve } \\
\text { üzeri }\end{array}$} & Adet & 954 & 701 & 108 & 349 & 31 & 255 \\
\hline & & Hane-Gelir & $34,5 \%$ & $25,3 \%$ & $3,9 \%$ & $12,6 \%$ & $1,1 \%$ & $9,2 \%$ \\
\hline & & Sağlık Kurum Tercihi & $12,9 \%$ & $17,3 \%$ & $11,7 \%$ & $18,6 \%$ & 5,9 & $27 \%$ \\
\hline \multirow{3}{*}{ Toplam } & & Adet & 7.387 & 4.045 & 926 & 1.880 & 525 & 944 \\
\hline & & Hane-Gelir & $42,8 \%$ & $23,5 \%$ & $5,4 \%$ & $10,9 \%$ & $3 \%$ & $5,5 \%$ \\
\hline & & Sağlik Kurum Tercihi & $100 \%$ & $100 \%$ & $100 \%$ & $100 \%$ & $100 \%$ & $100 \%$ \\
\hline
\end{tabular}

Sağlık kurumu tercihinde sosyal güvenceden yararlanabilecek olma (\% 42,8) ve sağlik kurumun yakınlığının $(\% 23,5)$ bütün gelir gruplar1 için temel etken olduğu görülmektedir. Ancak söz konusu iki faktörün belirleyicilik etkisi, gelir düzeyi yükseldikçe azalmaktadır. Bununla birlikte en düşük gelir grubundakiler için sağlık kurumu tercih ederken başka seçeneğin yokluğu ve ucuzluk önceliğe sahipken, gelir düzeyi yükseldikçe önceliği daha iyi sağlık hizmeti ve güvenilirlik oluşturmaktadır.

Bu çerçevede elde edilen bulgular doğrultusunda "H1.3: Sağlık talebinde bulunanlanın sağlık kurumu tercih sebepleri gelir düzeyine bağlı olarak değişkenlik göstermektedir” hipotezi kabul edilmektedir.

\section{Gelir Düzeyi ve Sağlık Hizmet Talebinde Bulunmama Hali İlişkisi}

Örneklem kapsamında sağlık hizmet talebinde bulunma oranının \% 69,2 olduğu oranında olduğu ve detayları Tablo 7 kapsamında değerlendirilmiştir. Son 12 aylık süreçte sağlık hizmet talebinde bulunmayan \%30’luk bölümü ise, sağlık hizmetine ihtiyaç duyulmaması ve sağlık hizmetine ihtiyaç duyulduğu halde söz konusu sağlık hizmetini karşılamaya yönelik ödeme gücü yoksunluğu nedeniyle talebin ortaya çıkmadı̆̆1 iki hale karşılık gelmektedir. Sağlık hizmeti talep nedeni, TÜİK tarafından yapılan anket formu kapsamında tıbbi bakım, diş bakımı, ilaç temini ve ruhsal tedavi olarak dört gruba ayrılmıştır.

Tablo 10. Gelir Düzeyi ve Sağllk Hizmet Talebi Olusmaması hali İlişkisi için Tek Yönlü V aryans (ANOVA) Analizi Sonuçlar

\begin{tabular}{|c|c|c|c|c|c|c|}
\hline & & $\begin{array}{c}\text { En Kü̧̈ük Kareler } \\
\text { Toplamı }\end{array}$ & $\begin{array}{c}\text { Serbestlik } \\
\text { Derecesi }\end{array}$ & Ortalama & F Değeri & Anlamlilik \\
\hline \multirow{3}{*}{ TIBBİ BAKIM } & Gruplar Aras1 & 36,715 & 4 & 9,179 & 54,029 & 0,000 \\
\hline & Grup İçi & 2928,269 & 17,237 & 0,170 & & \\
\hline & Toplam & 2964,983 & 17,241 & & & \\
\hline \multirow{3}{*}{ DİŞ BAKIM } & Gruplar Aras1 & 10,939 & 4 & 2,733 & 13,227 & 0,000 \\
\hline & Grup İçi & 3561,385 & 17,237 & 0,207 & & \\
\hline & Toplam & 3572,317 & 17,241 & & & \\
\hline \multirow{3}{*}{ İLAÇ TEMİN } & Gruplar Aras1 & 27,252 & 4 & 6,813 & 55,575 & 0,000 \\
\hline & Grup İçi & 2113,111 & 17,237 & 0,123 & & \\
\hline & Toplam & 2140,363 & 17,241 & & & \\
\hline \multirow{3}{*}{ RUHSAL TEDAVİ } & Gruplar Aras1 & 2,267 & 4 & 0,567 & 2,759 & 0,000 \\
\hline & Grup İçi & 3542,012 & 17,237 & 0,205 & & \\
\hline & Toplam & 3544,282 & 17,241 & & & \\
\hline
\end{tabular}

Tek yönlü varyans (ANOVA) analizi sonuçlarına göre gelir düzeyleri arasında ödeme güçlüğü nedeniyle sağlık hizmet talebinin oluşamamasının gösterdiği farklılığın anlamlı olduğu (p:0,000) tespit edilmiştir. Bu doğrultuda sağlık hizmet talebinin ortaya çıkmasının gelir düzeyine bağlı değişkenlik gösterdiği söylenebilir. 
Buna göre sağlık hizmetinin ihtiyaç olmaması ve ödeme gücü yoksunluğu nedeniyle ortaya çıkmaması hallerinin gelir düzeyi ile karşılaştırmalı olarak değerlendirilebilmesi amacıyla çapraz tablolar oluşturulmuştur.

Tablo 11. Gelir Düzeyi ile Sağhlk Hižmet Talebine İbtiyaç Olmaması Halinin Karşılaștırması

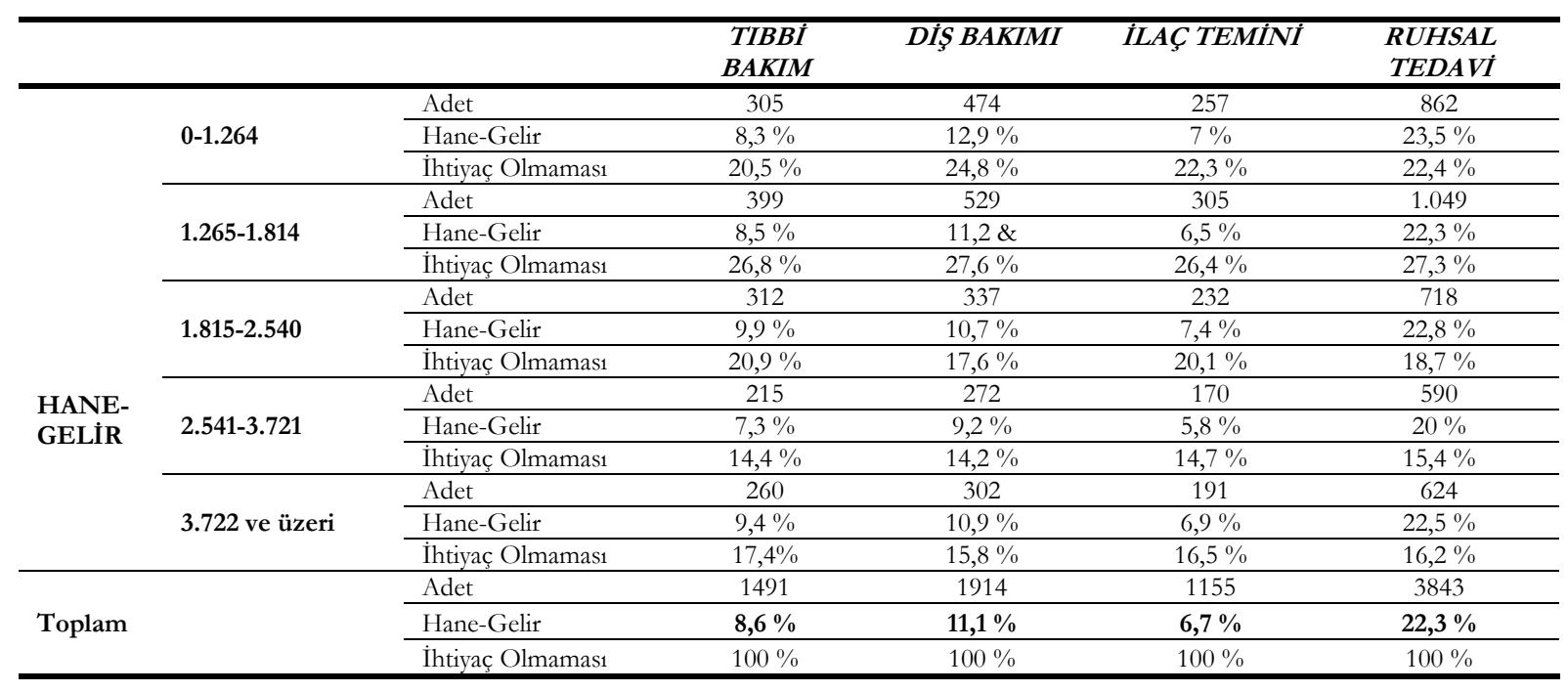

Sağlık hizmeti ihtiyacı duyulmaması nedeniyle sağlık hizmet talebinde bulunmayanların örneklem kapsamındaki oranına bakıldığında tıbbi bakım için \%8,6, diş bakımı için \% 11,1, ilaç temini için \% 6,7 ve ruhsal tedavi için \% 22,3 düzeyinde olduğu görülmektedir. Gelir düzeyi bağlamında ele alındığında genel ve kapsayıcı nitelikli olan tıbbi bakım talebine yönelik ihtiyaç bulunmaması hali gelir düzeyi artışı ile artarken, diş bakım talebine yönelik ihtiyaç bulunmaması hali gelir düzeyi artışı ile azalmaktadır. Bu durum, tıbbi bakımın zorunluluk niteliğinin diş bakımının zorunluluk niteliğinden daha yüksek olması şeklinde değerlendirilebilir. Buna bağlı olarak da gelir düzeyi düştükçe sağılk hizmet talebinde zorunluluk unsurunun daha belirleyici olduğu söylenebilir.

Diğer taraftan ilaç temini (\%7 civarında) ve ruhsal tedavi (\%22 civarında) talebinin bulunmamasında gelir düzeyine bağl1 belirgin bir fark olmadığı görülmektedir.

Tablo 12. Gelir Düzeyi ile Sağhlk Hižmet Talebinde Bulunamama Halinin Karşılaştırması

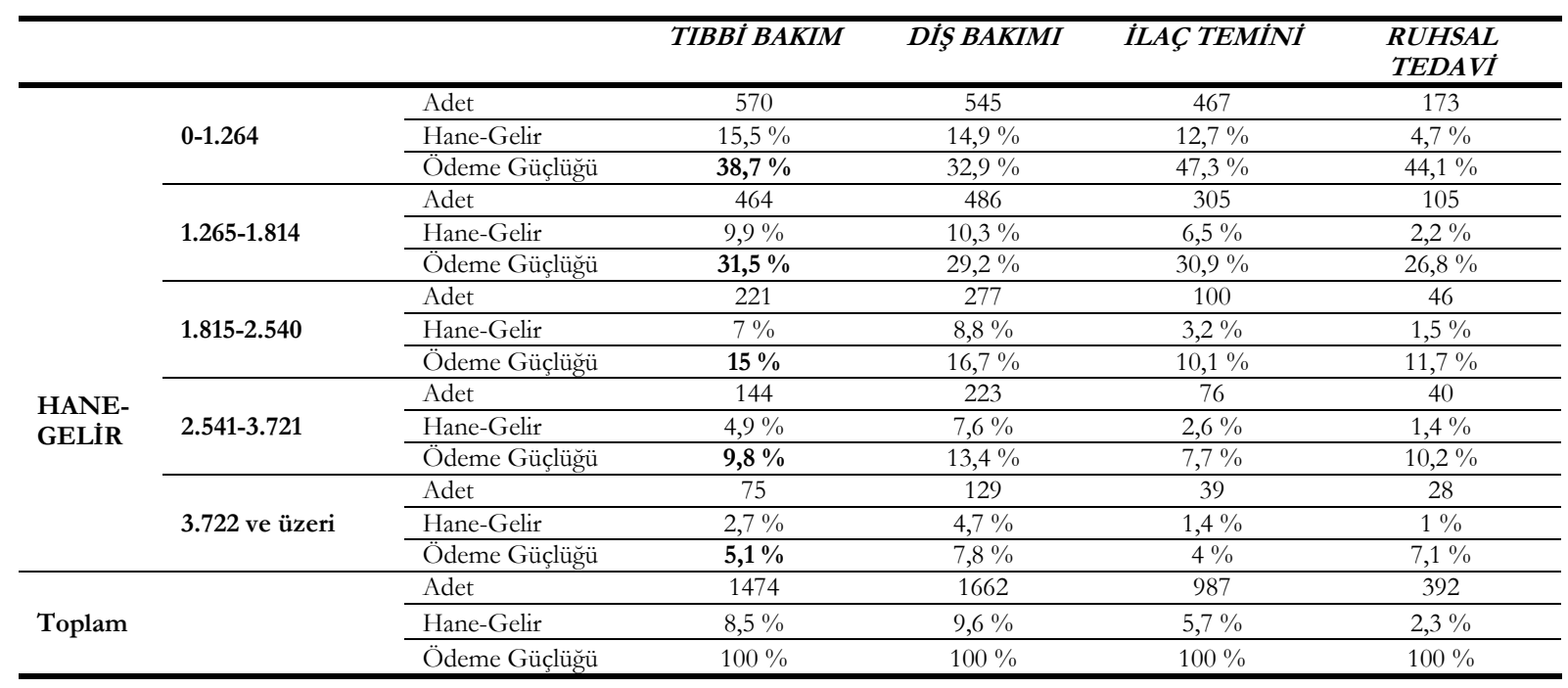

Ödeme gücü yoksunluğu nedeniyle sağlık hizmet talebinde bulunmayanların örneklem kapsamındaki oranına bakıldığında tıbbi bakım için \% $\%, 5$, diş bakımı için \% 9,6, ilaç temini için \% 5,7 ve ruhsal tedavi için \% 2,3 düzeyinde olduğu görülmektedir. Gelir düzeyi bağlamında ele alındığında dört sağlık hizmet nedeni için de ödeme güçlügü nedeniyle sağlık hizmet talebinde bulunamama hali gelir düzeyi artışı ile belirgin şekilde azalmaktadır. Özellikle en düşük iki gelir grubunun toplam \%25'lik kısmının ödeme güçlüğü nedeniyle tıbbi bakım ve diş bakımı hizmet talebinde bulunamadığı görülmektedir. 
DOĞAN

Gelir Düzeyi ve Să̆lık Hizmet Talebi İlişkisi: Mikro Veriler ile Türkiye Örneği

Bu çerçevede elde edilen bulgular doğrultusunda "H1.4: Ödeme güçlüğü nedeniyle sağlık talebinde bulunmama gelir düzeyine bağlı olarak değişkenlik göstermektedir” hipotezi kabul edilmektedir.

\section{Zaman Bağlamında Sağlık Hizmet Talebine İlişkin Bulgular}

Sağllk hizmet alımında zamanın problem olarak ortaya çıması, sağllk hizmetinden birilerinin yararlanmasının diğerlerinin yararlanma düzeyini azaltması halinde gerçekleşecektir. Sağılk hizmet talebindeki yoğunluğa bağlı olarak ortaya çıan bu kalabalıklaşma maliyeti beraberinde hizmet kullanıcıları arasında rekabeti de içermektedir. Bu durumun tespitine yönelik genel sağllk durumu ve sağllk sebebiyle günlük yaşam faaliyeti kısıtlananların sağlık hizmeti almada gecikme yaşayıp yaşamadıkları incelenecektir Bu doğrultuda ilk olarak sağılk hizmeti almada gecikme yaşanma oranını ortaya koymak amacıyla frekans analizi yapılımışır.

Tablo 13. Sağhlk Hiæmeti Almada Gecikme Değģskeni için Frekans Analiz̨i Sonuclar

\begin{tabular}{lcc}
\hline \multicolumn{1}{c}{ Sağhlk Hizmeti Almada Gecikme } & Slklık & Yüzde \\
\hline Evet & 2524 & 14,6 \\
Hayır & 13877 & 80,5 \\
İhtiyacım olmadı & 841 & 4,9 \\
\hline
\end{tabular}

Örneklem kapsamındaki hane halkının yaklaşık \%5'lik kısmı sağlık hizmetine ihtiyaç duymazken, \%15’lik kısmı da randevu alma süresinin uzunluğu nedeniyle sağlık hizmeti almada gecikme yaşamıştır. Bununla birlikte sağlık hizmeti almada gecikme yaşamayanların oranının (\%80,5), gecikme yaşayanlardan oldukça yüksek olması niceliksel olarak olumlu olmakla birlikte, yaşanan gecikmenin genel sağlık durumu bağlamında farklılık göstermesi halinde söz konusu niceliksel üstünlük durumun olumlu değerlendirilebilmesi için yeterli olmayacaktır. Bu doğrultuda sağlık hizmeti almada yaşanan gecikmenin genel sağlık durumuna göre farklllık gösterip göstermediğinin tespitine yönelik tek yönlü varyans (ANOVA) analizi yapilmıştır.

Tablo 14. Sağhlk. Hižmeti Almada Gecikme ve Genel Sağhk Durumu Illiskisi için Tek Yönlü Varyans (ANOVA) Analizi Sonuclar

\begin{tabular}{lccccc}
\hline & En Küçük Kareler Toplami & Serbestlik Derecesi & Ortalama & F Değeri & Anlamlilk \\
\hline Gruplar Aras1 & 194,721 & 2 & 97,360 & 137,933 & 0,000 \\
\cline { 1 - 3 } Grup İçi & 12168,155 & 17,239 & 0,706 & & \\
\cline { 1 - 3 } Toplam & 12362,876 & 17,241 & & & \\
\hline
\end{tabular}

Tek yönlü ANOVA testi sonuçlarına göre genel sağlık durumuna göre sağllk hizmeti almada gecikme yaşanması hali arasında anlamlı bir farklılık olduğu (p:0,000) tespit edilmiştir. Söz konusu farklılığın ortaya konulabilmesi ve sağlık hizmet alımında yaşanan gecikme ile genel sağlık durumu arasındaki ilişkinin karşlaştırılabilmesi için çapraz tablo oluşturulmuştur.

Tablo 15. Sağhle Hižmeti Almada Gecikme ve Genel Sağhle Durumu Karşılaștırması

\begin{tabular}{|c|c|c|c|c|c|c|c|c|}
\hline & & & \multicolumn{6}{|c|}{ GENEL SAĞLIK DURUMU } \\
\hline & & & $\begin{array}{c}\text { ÇOK } \\
I Y I I \\
\end{array}$ & $\dot{I} \boldsymbol{I} \dot{I}$ & ORTA & KÖTÜ & $\begin{array}{c}\text { COOK } \\
\text { KÖTÜ }\end{array}$ & TOPLAM \\
\hline \multirow{12}{*}{$\begin{array}{l}\text { SAĞLIK } \\
\text { HİZMETİ } \\
\text { ALMADA } \\
\text { GECÍKME }\end{array}$} & \multirow{3}{*}{ EVET } & Say1 & 15 & 1121 & 902 & 308 & 35 & 2524 \\
\hline & & Gecikme & $6,26 \%$ & $44,41 \%$ & $35,74 \%$ & $12,20 \%$ & $1,39 \%$ & $100,00 \%$ \\
\hline & & Genel Sağlık Durumu & $10,17 \%$ & $12,86 \%$ & $18,40 \%$ & $16,63 \%$ & $16,28 \%$ & $14,64 \%$ \\
\hline & \multirow{3}{*}{ HAYIR } & Say1 & 1227 & 7082 & 3877 & 1513 & 178 & 13877 \\
\hline & & Gecikme & $8,84 \%$ & $51,03 \%$ & $27,94 \%$ & $10,90 \%$ & $1,28 \%$ & $100,00 \%$ \\
\hline & & Genel Sağlık Durumu & $78,96 \%$ & 81,22 & 79,11 & 81,70 & 82,79 & 80,48 \\
\hline & \multirow{3}{*}{$\begin{array}{l}\text { IHTIYACIM } \\
\text { OLMADI }\end{array}$} & Say1 & 169 & 517 & 122 & 31 & 2 & 841 \\
\hline & & Gecikme & $20,10 \%$ & $61,47 \%$ & $14,51 \%$ & $3,69 \%$ & $0,24 \%$ & $100,00 \%$ \\
\hline & & Genel Sağlık Durumu & $10,88 \%$ & 5,93 & 2,49 & 1,67 & 0,93 & 4,88 \\
\hline & \multirow{3}{*}{ TOPLAM } & Say1 & 1554 & 8720 & 4901 & 1852 & 215 & 17242 \\
\hline & & Gecikme & $9,01 \%$ & $50,57 \%$ & $28,42 \%$ & $10,74 \%$ & $1,25 \%$ & $100,00 \%$ \\
\hline & & Genel Sağlık Durumu & $100,00 \%$ & $100,00 \%$ & $100,00 \%$ & $100,00 \%$ & $100,00 \%$ & $100,00 \%$ \\
\hline
\end{tabular}

Sağlık hizmeti almada gecikme yaşayanların önemli bir kısmının genel sağlık durumunun iyi $(\% 44,41)$ ve orta seviyede $(\% 35,74)$ olduğu görülmektedir. Bu durumun ortaya çıkmasında örneklem kapsamındaki hane halkının önemli bir kısmının genel sağlık durumunun iyi ve orta seviyede olmasının da etkili olması göz ardı edilemez. Nitekim her bir sağlık seviyesi için sağlık hizmeti alımında gecikme yaşanması hali ayrı ayr1 incelendiğinde orta $(\% 18,40)$, kötü $(\% 16,63)$ ve çok kötü $(\% 16,28)$ seviyedeki genel sağllk durumundakilerin gecikme yaşama oranının daha yüksek olduğu görülmektedir. 
$\mathrm{Bu}$ çerçevede "H2.1:Sağlık hizmeti almada gecikme yaşayanlar genel sağllk durumuna göre değişkenlik göstermektedir" hipotezi kabul edilmektedir.

Diğer taraftan genel sağlık durumu kötü olanların sağlık durumu nedeniyle günlük yaşam faaliyetlerinin kısıtlanma hali de göz önünde bulundurulduğunda sağlık hizmet alımında yaşanan gecikmenin önemi daha da artmaktadır. Bu doğrultuda sağlık hizmeti almada yaşanan gecikmenin sağllk sebebiyle yaşam faaliyetlerinin kıstllanma düzeyine göre farkll1ık gösterip göstermediğinin tespitine yönelik tek yönlü Anova Testi yapılmıştır.

Tablo 16. Sağhle Hižmeti Almada Gecikme ve Yaşam Faaliyetini Kısıtlaync Sağhk Problemi Bulunması Illiskisisi için Tek Yönlü Varyans (ANOVA) Analizi Sonuclar

\begin{tabular}{|c|c|c|c|c|c|}
\hline & En Küçük Kareler Toplamı & Serbestlik Derecesi & Ortalama & F Değeri & Anlamlilik \\
\hline Gruplar Aras1 & 78,098 & 2 & 39,049 & 88,644 & 0,000 \\
\hline Grup İçi & 7593,983 & 17,239 & 0,441 & & \\
\hline Toplam & 7672,081 & 17,241 & & & \\
\hline
\end{tabular}

Tek yönlü varyans (ANOVA) analizi sonuçlarına göre yaşam faaliyetlerinin kısıtlanma düzeyi ile sağlık hizmeti almada gecikme yaşanması hali arasında anlamlı bir farklılık olduğu (p:0,000) tespit edilmiştir. Söz konusu farklıllğın ortaya konulabilmesi ve değerlendirilebilmesi için çapraz tablo oluşturulmuştur.

Tablo 17. Sağhlk Hižmeti Almada Gecikme ve Yaşam Faaliyetini Kısıtlayıcı Sağhlk Problemi Bulunması Durumu Karşlasstormast

\begin{tabular}{|c|c|c|c|c|c|c|}
\hline & & & \multicolumn{4}{|c|}{ YAŞAM FAALIIYETLERINIINN KISITLANMA DURUMU } \\
\hline & & & $\begin{array}{l}\text { Ciddi Ölçüde } \\
\text { Kısıtlandı }\end{array}$ & $\begin{array}{c}\text { Kısıtlandı (Ciddi Ölçüde } \\
\text { Değgil) }\end{array}$ & Kisitlanmadi & TOPLAM \\
\hline \multirow{12}{*}{$\begin{array}{l}\text { SAĞLIK } \\
\text { HİZMETİ } \\
\text { ALMADA } \\
\text { GECİKME }\end{array}$} & \multirow[b]{3}{*}{ EVET } & Say1 & 308 & 920 & 1296 & 2524 \\
\hline & & Gecikme & $12,20 \%$ & $36,45 \%$ & $51,35 \%$ & $100,00 \%$ \\
\hline & & $\begin{array}{l}\text { Yaşam Faaliyet } \\
\text { Kisitlanma }\end{array}$ & $18,32 \%$ & $17,22 \%$ & $12,68 \%$ & $14,64 \%$ \\
\hline & \multirow[b]{3}{*}{ HAYIR } & Say1 & 1345 & 4262 & 8270 & 13877 \\
\hline & & Gecikme & $9,69 \%$ & $30,71 \%$ & $59,60 \%$ & $100,00 \%$ \\
\hline & & $\begin{array}{l}\text { Yaşam Faaliyet } \\
\text { Kisitlanma }\end{array}$ & $80,01 \%$ & $79,75 \%$ & $80,94 \%$ & 80,48 \\
\hline & \multirow[b]{3}{*}{$\begin{array}{l}\text { İHTİYACIM } \\
\text { OLMADI }\end{array}$} & Say1 & 28 & 162 & 651 & 841 \\
\hline & & Gecikme & $3,33 \%$ & $19,26 \%$ & $77,41 \%$ & $100,00 \%$ \\
\hline & & $\begin{array}{l}\text { Yaşam Faaliyet } \\
\text { Kisitlanma }\end{array}$ & $1,67 \%$ & $3,03 \%$ & $6,37 \%$ & $4,88 \%$ \\
\hline & \multirow[b]{3}{*}{ TOPLAM } & Say1 & 1681 & 5344 & 10217 & 17242 \\
\hline & & Gecikme & $9,75 \%$ & $30,99 \%$ & $59,26 \%$ & $100,00 \%$ \\
\hline & & $\begin{array}{l}\text { Yaşam Faaliyet } \\
\text { Kısıtlanma }\end{array}$ & $100,00 \%$ & $100,00 \%$ & $100,00 \%$ & $100,00 \%$ \\
\hline
\end{tabular}

Sağlık sebebiyle yaşam faaliyetlerinde kısıtlanma yaşamayanlar örneklem kapsamındaki hane halkının önemi bir kısmını $(\% 59,26)$ oluşturduğu gibi, sağlık hizmeti alımında gecikme yaşayanların da oransal olarak önemli bir kısmını (\%51,35) oluşturmaktadır. Bununla birlikte kısıtlama yaşamayanların, sağlık hizmeti almada gecikme yaşama oranının $(\% 12,68)$ kısıtlama yaşayanlara göre $(\% 18,32)$ düşük olduğu görülmektedir. Dolayısıyla sağlık sebebiyle günlük yaşamdaki kısıtlılık düzeyi arttıkça sağlık hizmeti almada yaşanan gecikmenin de oransal olarak artış gösterdiği söylenebilir.

Bu çerçevede "H2.2: Sağlık hizmeti almada gecikme yaşayanlar yaşam faaliyetlerinin kısıtlanma durumuna göre değişkenlik göstermektedir" hipotezi kabul edilmektedir.

\section{Araştırma Bulgularının Değerlendirilmesi}

Araştırmanın kurgusunu oluşturan iki temel hipoteze yönelik değerlendirmeler genel olarak ele alındı̆̆ında;

- İlk hipotez kapsamında genel sağlık durumu, talep edilen sağllk hizmetinin türü, sağlık kurumunun talep edilme gerekçesi, sağlık hizmet talebinde bulunmama ve bulunamama durumlarının tamamında gelir düzeyine bağlı farklılık olduğu sonucuna ulaşılmıştır. Buna göre gelir düzeyi daha düşük olanların genel sağlık durumları daha kötü olup, sağllk kurumu tercihinde ucuzluk ve yakınlığa verdikleri önemin göreli olarak daha yüksek olduğu, ödeme güçlüğü nedeniyle sağllk hizmet talebinde bulunamama oranlarının da belirgin ölçüde yüksek olduğu görülmüștür. $\mathrm{Bu}$ 
hipotez kapsamında elde edilen sonuçlar gelirin sağlık hizmet talebi üzerindeki etkisine ilişkin literatürde yer alan genel kabul ile de uyumluluk göstermektedir.

- İkinci hipotez kapsamında sağlık hizmeti almada yaşanan gecikmenin, genel sağlık durumu ve sağllk durumu nedeniyle günlük yaşam faaliyetlerinin kısıtlanması hallerine bağlı olarak farklılaştı̆̆ sonucuna ulaşılmıştır. Buna göre genel sağlık durumu kötü olanların ve sağlık problemi nedeniyle yaşam faaliyetleri kısıtlananların sağlık hizmeti almada gecikme yaşama oranının daha yüksek olduğu görülmüştür. Bu hipotez kapsamında elde edilen sonuçlar ise zaman maliyetinin sağlık hizmet talebinde önemli olduğunu ortaya koyan literatürdeki çalışmalar ile uyumluluk göstermektedir. Bununla birlikte hastalığın şiddeti arttıkça zamana verilen önemin arttığını ortaya koyan Akyürek ve Orhaner (2017) ile Gökkaya ve Erdem'in (2017) Türkiye örneklemine ilişkin çalışmalarından farklılık göstermektedir. Bu farklılığın da söz konusu çalışmalarda zaman maliyetinin gelir grupları arasındaki farklılık temelinde ele alınmayıp örneklem geneline ilişkin bir değerlendirme olmasından kaynaklandığı söylenebilir.

Her iki temel hipotez çalşsmanın teorik alt yapısı bağlamında ele alındığında; ilk hipotez ile gelir düzeyine bağlı olarak oluşan farkllıklar nedeniyle sağlık hizmetinde gelirin doğrudan etkisinin ortaya çıktığı; ikinci hipotez ile hizmet almada yaşanan gecikmeler dolayısıyla sağlık hizmetinde zaman etkisinin ortaya çıktığ1 söylenebilir. Bu doğrultuda örneklem kapsamında sağlık hizmet talebi üzerinde gelirin doğrudan ve dolaylı etkisinin eşanlı ortaya çıkıp çıkmadığının sorgulanması amacıyla her iki hipotezin ayıı ayrı sorgulanmasına imkan veren sorular, oluşturulan çapraz tablolar ile karşılaştırmalı olarak sorgulanmiştır.

Tablo 18. Gelir Düzeyi ve Sağhlk Hižmeti Almada Gecikme Yaşanması Durumu Karşılaş̆tırması

\begin{tabular}{|c|c|c|c|c|c|c|}
\hline & & & \multicolumn{4}{|c|}{ 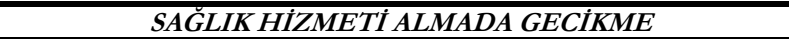 } \\
\hline & & & $\overline{E V E T}$ & HAYIR & $\begin{array}{c}\dot{I H T I Y A C I M} \\
\text { OLMADI }\end{array}$ & TOPLAM \\
\hline \multirow{15}{*}{$\begin{array}{l}\text { HANE- } \\
\text { GELİR }\end{array}$} & \multirow{3}{*}{$0-1.264$} & Adet & 413 & 3013 & 245 & 3671 \\
\hline & & Hane-Gelir & $16,40 \%$ & $21,70 \%$ & $29,10 \%$ & $21,30 \%$ \\
\hline & & Gecikme & $11,30 \%$ & $82,10 \%$ & $6,70 \%$ & $100,00 \%$ \\
\hline & \multirow{3}{*}{$1.265-1.814$} & Adet & 674 & 3795 & 238 & 4707 \\
\hline & & Hane-Gelir & $26,70 \%$ & $27,30 \%$ & $28,30 \%$ & $27,30 \%$ \\
\hline & & Gecikme & $14,30 \%$ & $80,60 \%$ & $5,10 \%$ & $100,00 \%$ \\
\hline & \multirow{3}{*}{$1.815-2.540$} & Adet & 480 & 2536 & 136 & 3152 \\
\hline & & Hane-Gelir & $19,00 \%$ & $18,30 \%$ & $16,20 \%$ & $18,30 \%$ \\
\hline & & Gecikme & $15,20 \%$ & $80,50 \%$ & $4,30 \%$ & $100,00 \%$ \\
\hline & \multirow{3}{*}{ 2.541-3.721 } & Adet & 477 & 2344 & 123 & 2944 \\
\hline & & Hane-Gelir & $18,90 \%$ & $16,90 \%$ & $14,60 \%$ & $17,10 \%$ \\
\hline & & Gecikme & $16,20 \%$ & $79,60 \%$ & $4,20 \%$ & $100,00 \%$ \\
\hline & \multirow{3}{*}{3.722 ve üzeri } & Adet & 480 & 2189 & 99 & 2768 \\
\hline & & Hane-Gelir & $19,00 \%$ & $15,80 \%$ & $11,80 \%$ & $16,10 \%$ \\
\hline & & Gecikme & $17,30 \%$ & $79,10 \%$ & $3,60 \%$ & $100,00 \%$ \\
\hline \multirow{3}{*}{ Toplam } & & Adet & 2524 & 13877 & 841 & 17242 \\
\hline & & Hane-Gelir & $100,00 \%$ & $100,00 \%$ & $100,00 \%$ & $100,00 \%$ \\
\hline & & Gecikme & $14,60 \%$ & $80,50 \%$ & $4,90 \%$ & $100,00 \%$ \\
\hline
\end{tabular}

Sağlık hizmeti almada gecikme yaşama oranında, en alt gelir grubu en düşük paya sahipken (\%16,40), ikinci en alt gelir gelir grubunun da en yüksek paya sahip olduğu $(\% 26,70)$, diğer üç gelir grubunun ise aldığı payın eşit (\%19) olduğu görülmektedir. Ancak bu dağllımda dikkat edilmesi gereken hususlar i) En düşük ikinci gelir grubu, örneklem kapsamında en yüksek sıklık düzeyine sahiptir, ii) Diğer dört gelir grubunda da gelir düzeyi yükseldikçe örneklem kapsamındaki sıklık düzeyi azalmıştır. Nitekim örneklem kapsamında gelir düzeyi yükseldikçe, sağlık hizmeti almada gecikme yaşama oranının da yükseldiği görülmektedir (En düşük gelir grubundakilerin sağlık hizmeti almada gecikme yaşama oranı en az $(\% 11,30)$, en yüksek gelir grubundakilerin oranı ise en yüksektir $(\% 17,30))$.

Sağlık hizmetlerinde kalabalık nedeniyle ortaya çıkan zaman maliyeti, bütün gelir grupları için geçerli olmakla birlikte, özellikle düşük gelir grupları için maliyetin etkisinin daha yüksek olması muhtemeldir. Bu durumun değerlendirilmesine yönelik, örneklem kapsamındaki düşük gelir grubundakilerin yaşadığı ödeme güçlüğü nedeniyle sağlık hizmeti talep edilememesi hali ile sağlık hizmeti almada gecikme yaşanması halinin karşlaştırılmasına imkan tanıyan çapraz tablo hazırlanmıştır. 


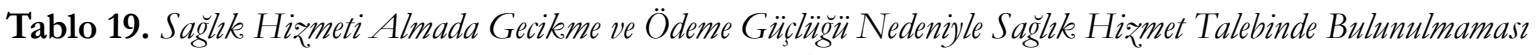
Durumu Karșılaștorması

\begin{tabular}{|c|c|c|c|c|c|c|}
\hline & & & \multicolumn{4}{|c|}{$\begin{array}{c}\text { ÖDEME GÜCGLÜĞ̈̈ NEDENİYLE SAĞLIK HİZMET } \\
\text { TALEBİNDE BULUNULAMAMASI HALI }\end{array}$} \\
\hline & & & $\begin{array}{c}T I B B \dot{I} \\
B A K I M\end{array}$ & $D \dot{I S S} B A K I M I$ & $\begin{array}{c}\dot{I} L A C \zeta \\
T E M I \dot{N} \dot{I}\end{array}$ & $\begin{array}{l}\text { RUHSAL } \\
\text { TEDAVII }\end{array}$ \\
\hline \multirow{12}{*}{$\begin{array}{l}\text { SAĞLIK } \\
\text { HİZMETİ } \\
\text { ALMADA } \\
\text { GECİKME }\end{array}$} & \multirow{3}{*}{ EVET } & Adet & 631 & 644 & 400 & 167 \\
\hline & & Gecikme & $25,00 \%$ & $25,50 \%$ & $15,80 \%$ & $6,60 \%$ \\
\hline & & Ödeme Güçlüğü & $42,80 \%$ & $38,70 \%$ & $40,50 \%$ & $42,60 \%$ \\
\hline & \multirow{3}{*}{ HAYIR } & Adet & 807 & 957 & 566 & 215 \\
\hline & & Gecikme & $5,80 \%$ & $6,90 \%$ & $4,10 \%$ & $1,50 \%$ \\
\hline & & Ödeme Güçlüğü & $54,70 \%$ & $57,60 \%$ & $57,30 \%$ & $54,80 \%$ \\
\hline & \multirow{3}{*}{$\begin{array}{l}\text { İHTİYACIM } \\
\text { OLMADI }\end{array}$} & Adet & 36 & 61 & 21 & 10 \\
\hline & & Gecikme & $4,30 \%$ & $7,30 \%$ & $2,50 \%$ & $1,20 \%$ \\
\hline & & Ödeme Güçlüğü & $2,40 \%$ & $3,70 \%$ & $2,10 \%$ & $2,60 \%$ \\
\hline & \multirow{3}{*}{ TOPLAM } & Adet & 1474 & 1662 & 987 & 392 \\
\hline & & Gecikme & $8,50 \%$ & $9,60 \%$ & $5,70 \%$ & $2,30 \%$ \\
\hline & & Ödeme Güçlüğü & $100,00 \%$ & $100,00 \%$ & $100,00 \%$ & $100,00 \%$ \\
\hline
\end{tabular}

Ödeme güçlüğü nedeniyle sağlık hizmet talebinde bulunamayanların yaklaşık \%40’lı kısmı sağlık hizmeti almada da gecikme yaşamıştır. Dolayısıyla ödeme güçlüğü nedeniyle sağlık hizmeti talep edemeyenlerin, sağlık hizmeti talep edebildikleri durumda da kalabalık nedeniyle sağlık hizmeti almada gecikme yaşamaları nedeniyle düşük gelir grubundakiler için sağlık hizmet talebi üzerinde gelirin doğrudan etkisinin yanı sıra dolaylı etkisinin de ortaya çıktı̆̆ı söylenebilir.

\section{Sonuç ve Öneriler}

Sağllk ekonomisi literatüründe sağllk hizmet talebini belirleyen faktörler, gerek teorik olarak gerekse söz konusu teorilerinin sorgulanmasına ve genişletilmesine imkan tanıyacak şekilde ampirik analizler araciliğıly incelenmiştir. Yapılan incelemeler sonucunda gelirin sağılk hizmet talebi üzerindeki etkisi literatürde genel bir kabul olarak ortaya koyulmuştur. Nitekim bu durum Türkiye'de uygulanan sağılk politikaları kapsamında da göz önünde bulundurularak, sağlık hizmetinin talep tarafinda bulunanların tamamı zorunlu olarak sigorta kapsamına dahil edilmiştir. Bu süreç Türkiye'de yllara yaygin olarak yürütülen sağlıkta dönüşüm programının en kapsamlı uygulaması olan ve 2008 yllinda yürürlüğe giren 31.05.2006 tarih ve 5510 saylı Sosyal Sigortalar ve Genel Sağllk Sigortası Kanunu kapsamında gerçekleştirilmiştir. Böylelikle sağlık hizmeti arz ve talep tarafinda bulunanların tamamı sosyal güvenlik şemsiyesi altında toplanmıştır. Buna bağlı olarak da genel sağlı sigortası kapsamındaki herkes prim yükümlüsü haline gelmiş, prime esas kazancın belirlenmesi ise hangi kategori bağlamında genel sağlık sigortası kapsamında yer alındığına bağlı olarak değişkenlik göstermektedir (Madde 80). Ancak bu düzenlemler ile her ne kadar herkese sağlık hizmeti tüketicisi niteliği verilmeye çalsşılsa da; zorunlu sağllk sigortası kapsamında, belirli sağılk hizmetlerinin kapsanması (Madde 63), sağlık hizmetinden yararlanmanın katkı payı gerektimesi (Madde 68) ve esas olarak da sağllk hizmetinden yararlanabilmenin ön koşulunun prime esas kazanç sahibi olmaya bağlı olması nedeniyle sağlık hizmeti talebi, gelir düzeyi bazlı bir oluşuma bağlı hale getirilmiştir.

Bu çalısma kapsamında da Türkiye'deki sağlık hizmet talebinde gelirin doğrudan ve zaman dolayımıyla ortaya çıkan dolaylı etkisine ilişkin sorgulama, literatürden hareketle TÜIKK tarafindan yayınlanan 2016 yll Sağllk Araştırması İstatistikleri kullanılarak ampirik temelde gerçekleştirilmiştir. Ampirik sorgulamanın temel hipotezleri, sağllk hizmet talebinde gelirin doğrudan ve zaman dolayımılla dolaylı etkisinin bulunup bulunmamasının testine yönelik olup; zaman için kalabalık nedeniyle randevu alma süresinde yaşanan gecikme durumuna, gelirin doğrudan etkisi için de ödeme güçlüğü nedeniyle sağlık hizmet talebinde bulunamama durumuna ilişkin veriler incelenmiştir. Yapılan analizler sonucu elde edilen bulgulara göre sağlık hizmet talebinde gelirin dolaylı $(\% 14,6)$ ve doğrudan (Tıbbi bakım: \%8,5; Diş bakım: \%9,6; İlaç temini: \%5,7; Ruhsal tedavi: \%2,3) etkilerinin birbirinden bağımsız olarak da, eşanlı olarak (Tıbbi bakım: \%3,7; Diş bakım: \%3,7; İlaç temini: \%2,4; Ruhsal tedavi: \%1) da ortaya çıktğı sonucuna ulaşılmıştır. Örneklem kapsamında gelirin doğrudan ve dolaylı etkisini eşanlı tecrübe edenler oransal olarak düşük olmakla birlikte (ortalama \%3); bu durumda olanların gelir seviyesi düşük gruplardan oluştuğu görülmüsstür. Dolayısıyla sağllk hizmet talebi bağlamında yüksek gelir grupları ile düşük gelir grupları arasında farklılık bulunduğu söylenebilir.

TÜİK verileri ile yapılan inceleme ile ulaşılan bu sonuçlar, yukarıda değinilen Türkiye'deki sağllk sistemi bağlamında ele alındığında, sağlık hizmeti talebinde düşük gelir gruplarının aleyhinde ortaya çıan gelir düzeyi temelli ayrım, mevcut sağlık sistemi kapsamında geçerli olan sağlık harcamalarının finansaman 
yöntemine ilişkin bir sorgulama gerekliliğine neden olmaktadır. Prime bağlı kazanç sistemine dayanan sosyal güvenlik sisteminin sağllk sistemindeki temel finansman yöntemi haline gelmesi, sağllk sisteminin kapsayıcılığına ilişkin bir sınırlamayı beraberinde getirmektedir. Bu koşullarda 5510 sayılı kanunun 67. Maddesinde belirtildiği gibi "18 yaşını doldurmamış olan kişiler, tıbben başkasının bakımına muhtaç olan kişiler, trafik kazası halleri, acil haller, iş kazası ile meslek hastalığı halleri, bildirimi zorunlu bulaşıc1 hastalıklar, madde bağımlılığı tedavisine yönelik sağlık hizmetleri, 63 üncü maddenin birinci fikrasının (a) ve (c) bentleri gereğince sağlanan sağllk hizmetleri, 75 inci maddede sayllan afet ve savaş ile grev ve lokavt hali hariç olmak üzere sağllk hizmetlerinden ve diğer haklardan yararlanabilmek için" sağllk hizmet sunucusuna başvuru tarihinden önceki son bir yl içinde otuz gün prim ödeme gün sayısının bulunması gibi koşullar bulunmaktadır. Söz konusu prim ödeme koşulunun yerine getirilmemesi ya da prim borcu bulunması hallerinde ise kamu sağlık hizmetinden yararlanma hakkı sağlanamamaktadır.

Diğer taraftan prime esas kazanç sahibi olmanın ötesinde genel sağlık sigortası kapasmında kamu sağlık hizmetleri sunumundan yararlanabilmek için 5510 sayll Kanunun 69. Maddesinde belirtilen durumların dışında katılım payı ödeme zorunluluğu bulunmaktadır. Özellikle de bu kanununun 68. Maddesinde belirtilildiği gibi ayakta tedavide hekim ve diş hekimi muayenesi ile ayakta tedavide sağlanan ilaçlar için katılım payı ödeme zorunluluğunun bulunması yaygın talebi olan sağlık hizmetlerinden yararlanabilinmesinin önüne gelir koşulunu getirmektedir. Bununla birlikte kanunun 69. Maddesi kapsamında sayllan hallerde katılım payı ödenme zorunluluğu bulunmamakta olup; bu hallerden aile hekimi muayeneleri ve kişiye yönelik koruyucu sağlık hizmetleri dışındaki hallerin tamamının (iş kazası, afet ve savaş hali, sağlık raporunun bulunması vb.) spesifik durumlara karşılık geldiği görülmektedir. Buna bağlı olarak da Genel Sağlık Sigortası kapsamında sağlık hizmetlerinden yararlanma hakkına sahip olunmasına rağmen, katılım payı ödenmeksizin bu haktan yararlanmak mümkün olamamaktadır.

Bu çerçevede TÜIKK verileri kullanılarak yapılan ampirik analiz sonuçlarına göre, sağlık hizmet talebinin gelir düzeyine bağlı olarak gösterdiği değişiklik litertürdeki genel kabul ile uyum göstermektedir. Bununla birlikte sağlık hizmet talebi üzerindeki gelirin etkisinin zaman maliyeti dolayısıyla da ortaya çıkması gelirin dolaylı etkisini de ortaya koymaktadır. Ulaşılan bu sonuçlar Türkiye'deki mevcut sağılk sistemi dahilinde ele alındı̆̆ında ise, Türkiye'de uygulanan ve prime esas kazanç temelinde kurgulanan sağlık politikalarının, gelir düzeyi farklliğı ve bu farklılık temelinde zaman maliyeti niteliğindeki sağlık hizmet talep sürecinde ortaya çıan elde edilemeyen gelirin artan önemi gibi hususları da içerecek şekilde revize edilmesi gerektiği söylenebilir. Nitekim yukarıda da belirtildiği gibi Genel Sağılk Sigortasından yaralanabilmenin temel koşulu prim ve katıllım payı ödemesine bağlanmakla birlikte, bu kapsamdaki istisnaların ise spesifik durum bazlı belirlenmesinin yeterli olmadığ1 düşünülmektedir. Bu doğrultuda birbirini tamamlayıcı nitelikte iki temel düzenleme önerisinde bulunulabilinir. İlk olarak ilgili spesifik durumların dışında gelir düzeyi açısından 5510 sayılı Kanun ele alındığında, Kanunun 60. Maddesinde yer alan ve aile içindeki geliri kişi başına düşen aylık tutarı asgari ücretin üçte birinden az olanların dışındakiler için, hangi gelir düzeyinde yer alınırsa alınsın prim ve katılım payı ödeme zorunluluğu bulunduğu görülmektedir. Bu kapsamda ilgili düzenlemelerde ödenecek prim ve kattlım paylarında (artan oranlı) gelir düzeyleri temelinde anlamlı bir farklılașturma yapılması önerilmektedir. Tamamlayıcı nitelikteki ikinci öneri ise, gelir düzeyleri temelinde yapılması önerilen farklılaşturmada, özellikle de düşük gelir grupları için gelir üzerindeki etkisi yüksek olan zaman maliyeti faktörünün de dikkate alınması gerektĭgidir. TÜIKK tarafindan hazırlanan "Türkiye Sağlık Araştırması" mikro verilerinden hareketle oluşturulan bu öneriler doğrultusunda yapılacak düzenlemler ile sağllk hizmet talebinde gelir düzeyinin belirleyici etkisinin azalacağı düşünülmektedir.

\section{Etik Beyan}

"Gelir Düzeyi ve Sağhk Hiæ̌met Talebi Ilişkisi: Mikero Veriler ile Türkiye Örmeği” başlıklı çalışmanın yazım sürecinde bilimsel, etik ve alıntı kurallarına uyulmuş; toplanan veriler üzerinde herhangi bir tahrifat yapılmamış ve bu çalışma herhangi başka bir akademik yayın ortamına değerlendirme için gönderilmemiştir”.

\section{Kaynakça}

Acton, J. P. (1975). Nonmenatry factors in the demand for medical services: Some empirical evidence. Journal of Political Economy, 83(3), 595-614. Erişim adresi: https://www.journals.uchicago.edu/doi/10.1086/260342

Akbari, A. H., Rankaduwa, W. ve Kiani, A. K. (2009). Demand for public health care in Pakistan. Pakistan Institute of Development Economics, 141-153. Erişim adresi: https://core.ac.uk/download/pdf/6543843.pdf

Akyürek, A. ve Orhaner, E. (2017). Özel hastanelere talebi etkileyen faktörler. Sağ̆lk. Akademisyenleri Dergisi, 4(4), 237 248. Erişim adresi: http://dergipark.org.tr/tr/download/article-file/751776 
Al-Ghanim, S. (2004). Factors influencing the utilisation of public and private primary healthcare services in Riyadh City. Journal of King Abduląiz University, 19(1), 3-27. Erişim adresi: https://www.kau.edu.sa/Files/320/Researches/51714_21849.pdf

Alpar, R. (2018). Spor, sağlık ve eğitim bilimlerinde örneklerle uygulamalı istatistik ve geçerlilik-güvenirlik. Ankara: Detay Yayıncilik.

Andersen, R. M. (1995). Revisiting the behavioral model and access to medical care: Does it matter?. Journal of Health and Social Behavior, 1-10. Erişim adresi: https://www.jstor.org/stable/2137284?seq=1

Arendt, J. N. (2012). The demand for health care by the poor under universal healthcare coverage. Journal of Human Capital, 6(4), 316-335. Erişim adresi: https://www.journals.uchicago.edu/doi/abs/10.1086/669139?mobileUi=0\&journalCode=jhc

Bircher, J. ve Kuruvilla, S. (2014). Defining health by addressing individual, social, and environmental determinants: New opportunities for health care and public health. Journal of Public Health Policy, 35(3), 363-386. Erişim adresi: https://www.ncbi.nlm.nih.gov/pubmed/24943659

Darlison, K. ve Okwi., P. (2011). Quality and demand for health care in rural Uganda: Evidence from 2002/2003 Household Survey. Nairobi: The African Economic Research Consortium.

Devaux, M. (2015). Income-Related inequities in health care services utilisation in 18 selected OECD Countries. The European Journal of Health Economics, 16(1), 21-33.

Fabbri, D. ve Monfardini, C. (2003). Public vs. private health care services demand in Italy. Giornale degli Economisti e Annali di Economia, Nuova Serie, 62(116), 93-123.

Fredericx, I. (1998). Health in rural Tanzania: The determinants of health status, health care demand and health care choice. Katholieke Universiteit Leuven Center for Economic Studies Discussion Paper Series 3.

Girma, F., Jira, C. ve Girma, B. (2011). Health services utilization and associated factors in Jimma Zone, Soth West Ethiopia. Ethiopian Journal of Health Sciences, 21, 91-100.

Glick,P., Razafindravonona, J. ve Randretsa, I. (2000). Education and health services in Madagascar: Utilization patterns and demand determinants. Cornell Food and Nutrition Policy Program Working Paper,107.

Gotsadze, G., Bennett, S., Ranson, K. ve Gzirishvili, D. (2005). Helath care-seeking behaviour and out-of pocket payments in Tbilisi, Georgia. Health Policy and Planing, 20(4), 232-242.

Gökkaya, D. ve Erdem, R. (2017). Sağlık hizmetleri kullanımına etki eden faktörlerin hastalık şiddeti algısıyla değerlendirilmesi. Süleyman Demirel Üniversitesi Sosyal Bilimler Enstitüsü Dergisi, 1(26), 149-184.

Grossman, M. (2017). On the concept of health capital and the demand for health. M. Grossman içinde, Determinants of Health: An Economic Perspective (s. 6-41). Columbia University Press.

Güneş, C., Ünlü, M., Büyükkör, Y. ve Birecikli, Ş. Ü. (2016). Türkiye'de săglık hizmetleri talebinin sayma veri modelleriyle incelenmesi: İçsellik sorunu. Sosyoekonomi, 24(30), 113-128. doi: https://doi.org/10.17233/se.2016.10.006

Habibov, N. (2009). What determines healthcare utilization and related out-of-pocket expenditures in Tajikistan? Lessons from a National Survey. International Journal of Public Health, 54(4), 260-266.

Habtom, G. K. ve Ruys P. (2007). The choice of a health care provider in Eritrea. Health Policy, 80(1), 202-217.

Hanson, K., Yip, W. C. ve Hsiao, W. (2004). The impact of quality on the demand for outpatient services in Cyprus. Health Economics, 13(12), 1167-1180.

Havemann, R. ve Berg, S. (2002). The demand for health care in South Africa. Stellenbosch Economic Working Papers, 6.

Heller, P. (1982). A model of the demand for medical and health services in Peninsular Malaysia. Social Science and Medicine, 16(3), 267-284.

Hotchkiss, D. R. (1998). The trade off between price and quality of services in the Philipness. Social Science and Medicine, 46(2), 227-242.

Howitt, D. ve Cramer, D. (2011). Introduction to SPSS statistics in psychology: For version 19 and earlier (Fifth edition). London: Pearson Education Limited.

Ichoku, H. E. ve Leibbrandt, M. (2003). Demand for healthcare services in Nigeria: A multivariate nested logit model. African Development Review, 15(2-3), 396-424.

Kermani, M. S., Ghaderi, H. ve Yousefi, A. (2008). Demand for medical care in the urban areas of Iran: An empirical investigation. Health Economics, 17(7), 849-862.

Kutlu, G. ve Ağırbaş, İ. (2017). Türkiye ve OECD ülkelerinde sağlık hizmetleri arzı ve talebinin incelenmesi. International Journal of Academic V alue Studies, 3(16), 454-464.

Lepine, A. ve Nestour, A. (2011). Health care utilization in rural Senegal: The facts before the extension of health insurance to farmers. Geneva: International Labour Office.

Liu, Y., Çelik, Y. ve Şahin, B. (2005). Türkiye'de sağhlk ve ilaş harcamaları. Sağlıkta Umut Vakfi.

McKillup, S. (2012). Statistics explained: An introductory guide for life scientists (Second edition). United States: Cambridge University Press.

Mertler, C. A. ve Vannatta, R. A. (2005). Advanced and multivariate statistical methods: Practical application and interpretation (third edition). United States: Pyrczak Publishing.

Muriithi, M. K. (2013). The determinants of health-seeking behaviour in a Naairobi Slum, Kenya. European Scientific Journal, 9(8), 151-164.

Ntembe, A. (2009). User charges and healthcare provider choice in Camerun. International Review of Business Research Papers, 5(6), 33-49. 
Quian, D., Pong, R. W., Yin, A., Nagarajan, K. V. ve Meng, Q. (2009). Determinants of health care demand in poor, rural China: The Case of Gansu Province. Health Policy and Planning, 24(5), 324-334.

Riphahn, R. T., Wambach, A. ve Million, A. (2003). Incentive effects in the demand for health care: A bivariate panel count data estimation. Journal of Applied Econometrics, 18(4), 387-405.

Saraçoğlu, S. ve Öztürk, F. (2015). Sağllk hizmetlerine yönelik talebin belirleyicileri: Türkiye üzerine bir uygulama. $\dot{I}_{s}$ ve Hayat, 293-342. Erişim adresi: http://dergipark.org.tr/tr/download/article-file/299583

Şantaş, F. (2017). Yoksulluğun sağlık statüsü ve sağlık hizmetleri kullanımı ile ilişkisi. Iğdır Üniversitesi Sosyal Bilimler Dergisi, 545-591. Erişim adresi: http://sosbilder.igdir.edu.tr/Makaleler/803868700_makale $\% 2023 \% 20$ say\%c4\%b1\%2013\%20f.\%20\%c5\%9fan ta $\%$ c $5 \% 9 \mathrm{f} \% 20$ pdf.pdf

Şenol, V., Çetinkaya, F. ve Balc1, E. (2010). Factors assocaited with health sevices utilization by the general population in the center of Kayseri, Turkey. Türkiye Klinikleri Tip Bilimleri Degisi, 30(2), 721-730.

Thuan, N. T. B., Lofgren, C., Lindholm, L. ve Chuc, N. T. K. (2008). Choice of healthcare provider following reform in vietnam. BMC Health Services Research, 8(162), 1-9.

Triyana, M. (2016). Do health care providers respond to demand-side incentives? Evidence from Indonesia. American Economic Journal: Economic Policy, 8(4), 255-288.

Türkiye İstatistik Kurumu Başkanlığı. "Türkiye sağlık araştırması 2016" mikro veri seti.

Xu, K., Carrin, G., Phuong, N. T. K., Long, N. H., Bayarsaikhan, D. ve Aguilar, A. M. (2006). Health service utilization and financial burden on households in Vietnam: The impact of social health insurance. World Health Organization Discussion Paper,6.

Yaylalı, M., Kaynak, S. ve Karaca, Z. (2012). Sağlik hizmetleri talebi: Erzurum ilinde bir araştırma. Ege Akademik Bakıss, 12(4), 563-573. Erişim adresi: http://dergipark.org.tr/tr/pub/eab/issue/39902/473806

\section{EXTENDED ABSTRACT}

Healthcare demand is a derived demand through demand for health. The demand for health services arises depending on the demand for health and the consumption of the health services provided. Health, which is defined by the criteria of economics within the scope of health economics, is defined in the World Health Organization (WHO) Constitution as "the state of physical, mental and social well-being, not just the absence of disease or defect". In the health economy literature, within the scope of the Meikirch Health Model, health is a state of welfare arising from the interaction between individuals' potentials, life demands and social and environmental factors (Bircher, \& Kuruvilla, 2014).

The broad definition of health not only extends the scope of the demand for health, but also expands the scope of the demand for health services. Accordingly, the factors that determine the demand for health services in the health economics literature consist of micro and social, cultural, religious and political variables such as prices, income level, time cost, health level and severity of the disease, health insurance ownership, demographic factors and the quality of health services provided. The first systematic models for healthcare demand were developed by Michael Grosmann, Jan Paul Acton and Ronald M. Andersen. Although Andersen (1995) provides an overview of the social determinants of health services, a fundamentally behavioral model has been developed. Unlike Andersan, the models developed by Grosmann and Acton are based on micro variables. Grosmann Health Demand Model has been developed on the basis of household production theory and is based on the difference between the demand for health and the demand for health services. It has the characteristics of consumption and investment goods produced through health, health services and time variables, which are seen as a basic good. Accordingly, in the model, the property of consumption goods is considered to be useless for the individual in the preference function of individuals, and the property of investment goods is accepted as the cash value of the elimination of losses caused by times when there is no health. Modeled by revealing its difference from other human capital investments, the Grossman health demand model is the first demand model in which health is taken as a capital stock. Accordingly, individuals born with a certain health stock can increase this value again by making a health investment against the decreases in the value of this stock (Grossman, 2017, s. 7-8). Similarly, Acton has also created a utility maximization model in micro quality health services by using Grossmann's model. However, in Acton's model, there is no distinction in terms of consumption and investment goods for health, and it is addressed within the scope of the problem of maximization of benefits determined by variables of health price, income and time. Accordingly, the consumer, acting with the motive of maximizing benefits, must pay a price or reduce the demand for other goods and services in order to request healthcare services under the budget constraint. In the model in which income is earned and the time allocated to health services is divided into two as unearned income, time is included as possible losses similar to Grossman model (Acton, 1975). 
The factors that determine the demand for health services in the health economics literature have been analyzed both theoretically and through empirical analyzes in a way that enables the questioning and extension of these theories. As a result of the examinations carried out, the effect of income on the demand for health care has been presented as a general acceptance. Indeed, in this case all of the demand side of health care, taking into consideration the context of the health policies implemented in Turkey has been included in the mandatory insurance coverage. This was carried out under the most comprehensive application that dated 31.05.2006 and entered into force in 2008 and 5510 Social Security and General Health Insurance Law of the health reform program conducted widely for years in Turkey. Thus, all those who are on the supply and demand side of the health service were gathered under the umbrella of social security. Accordingly, everyone within the scope of universal health insurance has become a premium liability, and the determination of the earnings based on premium varies depending on the category within the scope of general health insurance (Article 80). However, although these regulations are tried to be given to everybody as a healthcare consumer; Within the scope of compulsory health insurance, the demand for health services is based on income level-based formation, as coverage of certain health services (Article 63), the need to contribute to health care (68) and the prerequisite for benefiting from health care depends on having earnings based on premium has been connected. Grossman and Acton models, as well as being micro models, include the time allocated to healthcare demand as an alternative to the working time and therefore the opportunity to earn income, as well as the indirect effect that occurs through time, beyond the direct effect of income. Within the scope of this study, it is aimed to reveal not only the direct but also the indirect effect of income through time, taking into account the effect of income and time through health income demand in Grossman and Acton healthcare demand models. 